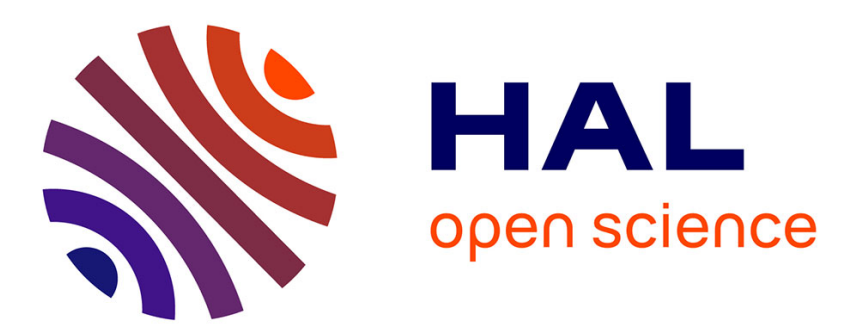

\title{
Two-stage Variscan metamorphism in the Canigou massif: evidence for crustal thickening in the Pyrenees
}

Luc de Hoÿm de Marien, Benjamin Le Bayon, Pavel Pitra, Jean van den

Driessche, Marc Poujol, Florence Cagnard

\section{- To cite this version:}

Luc de Hoÿm de Marien, Benjamin Le Bayon, Pavel Pitra, Jean van den Driessche, Marc Poujol, et al.. Two-stage Variscan metamorphism in the Canigou massif: evidence for crustal thickening in the Pyrenees. Journal of Metamorphic Geology, 2019, 37 (6), pp.863-888. 10.1111/jmg.12487 . insu-02106928

\section{HAL Id: insu-02106928 \\ https://hal-insu.archives-ouvertes.fr/insu-02106928}

Submitted on 23 Apr 2019

HAL is a multi-disciplinary open access archive for the deposit and dissemination of scientific research documents, whether they are published or not. The documents may come from teaching and research institutions in France or abroad, or from public or private research centers.
L'archive ouverte pluridisciplinaire $\mathbf{H A L}$, est destinée au dépôt et à la diffusion de documents scientifiques de niveau recherche, publiés ou non, émanant des établissements d'enseignement et de recherche français ou étrangers, des laboratoires publics ou privés. 
Title: Two-stage Variscan metamorphism in the Canigou massif: evidence for crustal thickening in the Pyrenees

Luc de Hoÿm de Marien ${ }^{1}$, Benjamin Le Bayon ${ }^{2}$, Pavel Pitra ${ }^{1,3}$, Jean Van Den Driessche ${ }^{1}$, Marc Poujol ${ }^{1}$ and Florence Cagnard ${ }^{2}$

${ }^{1}$ Univ Rennes, CNRS, Géosciences Rennes - UMR 6118, F-35000 Rennes, France

${ }^{2}$ Bureau de Recherches Géologiques et Minières - BRGM - 3 avenue Claude Guillemin, BP 36009, 45060 Orléans cedex 2, France

${ }^{3}$ Česká geologická služba, CZ-118 21 Prague 1, Czech Republic

Corresponding author: luc.dehoym@gmail.com

Running title: Variscan two-stage metamorphism, Pyrenees

\section{Abstract}

The Variscan metamorphism in the Pyrenees is dominantly of the low-pressure-high-temperature (LP-HT) type. The relics of an earlier, Barrovian-type, metamorphism that could be related to orogenic crustal thickening are unclear and insufficiently constrained. A microstructural and petrological study of micaschists underlying an Ordovician augen orthogneiss in the core of the Canigou massif (Eastern Pyrenees, France) reveal the presence of two syntectonic metamorphic stages characterized by the crystallization of staurolite (M1) and andalusite (M2), respectively. Garnet is stable during the two metamorphic stages with a period of resorption between $\mathrm{M} 1$ and

This article has been accepted for publication and undergone full peer review but has not been through the copyediting, typesetting, pagination and proofreading process, which may lead to differences between this version and the Version of Record. Please cite this article as doi: $10.1111 /$ jmg. 12487

This article is protected by copyright. All rights reserved. 
M2. The metamorphic assemblages $M 1$ and $M 2$ record similar peak temperatures of $580{ }^{\circ} \mathrm{C}$ at different pressure conditions of $5.5 \mathrm{kbar}$ and $3 \mathrm{kbar}$, respectively. Using chemical zoning of garnet and calculated $P-T$ pseudosections, a prograde $P-T$ path is constrained with a peak pressure at $\sim 6.5$ kbar and $550^{\circ} \mathrm{C}$. This $P-T$ path, syntectonic with respect to the first foliation $\mathrm{S} 1$, corresponds to a cold gradient (of $\sim 9{ }^{\circ} \mathrm{C} / \mathrm{km}$ ), suggestive of crustal thickening. Resorption of garnet between $\mathrm{M} 1$ and M2 can be interpreted either in terms of a simple clockwise $P-T$ path or a polymetamorphic two stage evolution. We argue in favour of the latter, where the medium-pressure (Barrovian) metamorphism is followed by a period of significant erosion and crustal thinning leading to decompression and cooling. Subsequent advection of heat, probably from the mantle, lead to a new increase in temperature, coeval with the development of the main regional fabric S2.

LA-ICP-MS U-Th-Pb dating of monazite yields a well-defined date at c. 300 Ma. Petrological evidence indicates that monazite crystallization took place close to the M1 peak-pressure conditions. However, the similarity between this age and that of the extensive magmatic event well documented in the eastern Pyrenees suggests that it probably corresponds to the age of monazite recrystallization during the $\mathrm{M} 2 \mathrm{LP}-\mathrm{HT}$ event.

Key words: Variscan Pyrenees, Barrovian metamorphism, pseudosections, polyphase $P-T$ path, crustal thickening

This article is protected by copyright. All rights reserved. 
Late low-pressure-high-temperature (LP-HT) metamorphism occurs in most orogens resulting from continental convergence, such as the European Variscan belt. This metamorphism is generally preceded by a higher-pressure metamorphic evolution, commonly of the Barrovian type, typically associated with crustal thickening responsible for a higher heat production (e.g. England \& Thompson, 1984). The subsequent horizontal ductile flow of the thermally relaxed thickened crust induces thinning and triggers the onset of exhumation processes and the associated LP-HT metamorphism.

The Variscan basement of the so-called Axial Zone of the Pyrenees (Figure 1a), is characterized by such a late pervasive LP-HT metamorphism. This metamorphism develops in gneissic to migmatitic dome-shaped structures that refold an initial flat-lying foliation, whereas a steeply dipping cleavage affects the overlying low-grade metamorphic rocks (De Sitter \& Zwart, 1960; Zwart, 1979). This vertical metamorphic and structural zonation led to contrasting interpretations ranging from transpressional to transtensional tectonics, including deformation partitioning between the lower and the upper crust (see Carreras \& Capella, 1994; Cochelin, Chardon, Denèle, Gumiaux, \& Le Bayon, 2017). Whatever their differences, most of these tectonic models imply an early crustal thickening. Previous petrological studies have documented or invoked an early medium-pressure (MP) metamorphism interpreted as the record of this crustal thickening (Aguilar et al., 2015; Mezger, Passchier, \& Régnier, 2004; Vilà, Pin, Liesa, \& Enrique, 2007). However, a syntectonic prograde up-pressure $P-T$ path that typifies crustal thickening has not yet been documented.

In the Canigou massif (Figure 1b), a previous petrological study of garnet-stauroliteandalusite bearing micaschists has interpreted garnet prograde growth zoning and andalusite crystallization after staurolite as the results of a prograde LP-HT metamorphism (Gibson, 1992). The

This article is protected by copyright. All rights reserved. 
subsequent discovery of kyanite associated with garnet and staurolite suggested that these porphyroblasts belonged to an earlier, higher-pressure, event (Azambre \& Guitard, 2001).

In order to document the early metamorphic and structural events that affected the Variscan basement in the Pyrenees, we reinvestigate the garnet-staurolite-andalusite bearing micaschists from the Canigou using a microstructural and pseudosection-based petrological approach. Our results reveal unequivocal evidence of crustal thickening and allow to discuss the subsequent exhumation and thermal evolution of these previously buried rocks.

\section{GEOLOGICAL SETTING}

\subsection{The Variscan Pyrenees: metamorphic and chronological framework}

Modern petrological studies on the Axial Zone of the Pyrenees (see Figure S1 for the localisation of the massifs mentioned hereafter) are relatively rare and infer contrasting peak $P-T$ conditions and $P-T$ paths (Figure 2; Table S1). They agree on the dominance of a LP-HT metamorphism $(P<\sim 4.5$ kbar, $T>\sim 550^{\circ} \mathrm{C}$ ) that would be achieved, however, through heating and decompression (Bossòst massif, Mezger \& Passchier, 2003; Albères, Vilà et al., 2007), isobaric heating or heating at increasing pressure (Aston-Hospitalet, Mezger \& Régnier, 2016), or cooling and decompression (Bossòst, Mezger et al., 2004; Roc de France, Aguilar et al., 2015). Importantly, although medium-pressure (MP) conditions ( $P>\sim 5$ kbar) are locally inferred (Aguilar et al., 2015; Mezger et al., 2004), no study documents the prograde $P-T$ path leading to the MP pressure peak.

The timing of the metamorphic events is also a matter of debate. On the one hand, $\mathrm{U}-\mathrm{Pb}$ dating on zircon and $\mathrm{U}-\mathrm{Th}-\mathrm{Pb}$ on monazite in granitic rocks and a paragneiss in the Bossòst and Aston-Hospitalet massifs yielded dates around $\sim 340-320 \mathrm{Ma}$, interpreted as the age of the LP-HT event (Mezger \& Gerdes, 2016). On the other hand, in many other studies, the widespread calcalkaline magmatism emplaced between $310-290 \mathrm{Ma}$ is considered coeval with the LP-HT

This article is protected by copyright. All rights reserved. 
metamorphism (e.g. Denèle et al., 2014 and references therein; Druguet, Castro, Chichorro, Pereira, \& Fernández, 2014). Separate metamorphic events or a single event diachronic across the Axial Zone have been proposed to account for these age populations (Mezger \& Régnier, 2016). Other authors argued in favour of an inherited component for the c. 340 Ma ages (see discussion in Denèle et al., 2014; Lopez-Sanchez, García-Sansegundo, \& Martínez, 2018).

Partial melting in the Roc de France massif is poorly constrained by U-Pb ages on zircon from leucosomes at $320 \pm 13$ and $313 \pm 13$ Ma (Aguilar, Liesa, Castiñeiras, \& Navidad, 2014). The subsequent exhumation of the migmatites occurred during a later thermal event constrained at 314$307 \mathrm{Ma}$ (Aguilar et al., 2014, 2015). In addition, in the Lys-Caillaouas massif, zircon grains from mafic and granitic magmatic rocks display cores and rims with metamorphic and magmatic affinities, respectively. The cores yield a date of c. $307 \mathrm{Ma}$, interpreted as the age of the thermal peak of the LP-HT metamorphism, while the magmatic overgrowths dated at c. $300 \mathrm{Ma}$ are interpreted as the age of the emplacement of the Lys-Caillaouas pluton (Esteban et al., 2015). To sum up, most authors agree that the dominant LP-HT metamorphism was contemporaneous with a widespread magmatic event that occurred 310-290 Ma ago.

\subsection{The Canigou Massif}

The Canigou is a gneissic dome-shaped massif of the Axial Zone located in the eastern Pyrenees (Figure 1a). It comprises orthogneiss, micaschists and undeformed granitoids. The massif is bounded to the north and to the south by roughly E-W trending shear zones (Guitard, Laumonier, Autran, Bandet, \& Berger, 1998; Laumonier, Le Bayon, \& Calvet, 2015). The Northern Canigou mylonitic zone, as well as the southern border of the orthogneiss were reactivated by south-vergent thrusting during the Alpine orogeny (Auriol \& Casteras, 1958; Fontboté \& Guitard, 1958). Finally, the Northern Canigou mylonitic zone was reactivated during the Oligocene opening of the Gulf of Lion (Maurel et al., 2008). Several Neogene NNE-SSW to E-W normal faults cut across the massif.

This article is protected by copyright. All rights reserved. 
The studied micaschists mostly outcrop in the central part of the dome, in the footwall of the orthogneisses, in the so-called "Balatg window" (Figure 1c). The main foliation, in both the micaschists and the orthogneisses, is parallel to the lithological contacts and outlines the dome shape of the massif (Figure 1b,c). The orthogneisses were derived from an Ordovician rapakivi granite (protolith ages at c. $475 \mathrm{Ma}$, Deloule, Alexandrov, Cheilletz, Laumonier, \& Barbey, 2002) that intruded Precambrian to Ordovician pelitic rocks (Barbey, Cheilletz, \& Laumonier, 2001; Padel et al., 2017). A weakly deformed monzogranite dyke, parallel to the main foliation, from the northern flank of the dome, has been dated at c. 305 Ma (Denèle et al., 2014). The undeformed Costabonne granite (Figure 1b) cuts across the main foliation. Its age is poorly constrained by U-Pb on zircon with two clusters at c. $302 \mathrm{Ma}(\mathrm{N}=2)$ and c. $285 \mathrm{Ma}(\mathrm{N}=8)$ (Laumonier et al., 2015).

$\mathrm{LP}-\mathrm{HT}$ regional metamorphic zoning is defined in the micaschists by the progressive appearance of chlorite, biotite, andalusite \pm cordierite, and sillimanite from the outer to the inner parts of the massif (Guitard, 1970). Increasing temperature during the LP-HT event is revealed by the growth of prismatic sillimanite after andalusite (Gibson, 1992). The peak $P-T$ conditions, constrained using conventional thermobarometry, reached 4.5 kbar and $~ 725^{\circ} \mathrm{C}$ (Gibson \& Bickle, 1994). Andalusite and cordierite locally contain inclusions of resorbed staurolite (Guitard, 1970). Staurolite porphyroblasts contain straight inclusion trails of ilmenite disposed at high angle relative to the external foliation (Gibson, 1991, 1992). Staurolite is associated with kyanite (Azambre \& Guitard, 2001) and helicitic or static garnet with prograde growth zoning (Gibson, 1992). The development of the main regional foliation is coeval with the crystallization of andalusite and cordierite. Their growth at the expense of staurolite was initially interpreted as the result of downpressure, up-temperature prograde metamorphism in an overall low-pressure setting (Gibson, 1992).

This article is protected by copyright. All rights reserved. 
The dome shape of the Canigou massif results from the refolding of the main regional foliation, S2. The strike of the foliation parallels the map outline of the massif and the dip increases from the core to the rim of the dome (Figure 1b). In the orthogneiss, this foliation is marked by the flattening of quartz and feldspars and by the preferential orientation of micas. Isoclinal folds, rarely observed in the orthogneiss (Figure $3 \mathrm{~d}$ ), indicate that the main planar fabric corresponds to a composite S1/S2 foliation.

The schistosity in the micaschists is parallel to the foliation in the orthogneiss. The micaschists display a compositional layering (SO), marked by alternating mica-rich and quartzfeldspar-rich layers, and interpreted as inherited from an original sedimentary structure. A first schistosity, S1, parallel to this layering, is defined by preferential orientation of micas. Both structures are folded (Figure 3a-c) mostly by isoclinal rootless folds. The main regional schistosity S2 is parallel to the axial plane of these folds and generally transposes S1. Consequently, the D1 structures are erased by D2 in most of the Canigou massif.

A lineation is oriented NE-SW and marked by the stretching of feldspar and quartz lenses in the orthogneiss. In the micaschists, it corresponds to the intersection between S2 and S1 and is parallel to the fold axes.

\section{PETROGRAPHY AND MINERAL CHEMISTRY}

Mineral analyses have been performed with a Cameca SX100 electron microprobe (Microsonde Ouest, IFREMER, Brest-Plouzané, France). Representative analyses of selected minerals are listed in Table 1. Mineral abbreviations are: all: allanite, and: andalusite, bi: biotite, camp: clinoamphibole, cd: cordierite, ep: epidote, g: garnet, ilm: ilmenite, ksp: potassium feldspar, ky: kyanite, ma: margarite, mt: magnetite, mu: muscovite, pa: paragonite, pl: plagioclase, q: quartz, ru: rutile, sill: 
sillimanite, sp: spinel, st: staurolite, wm: white mica. Mineral endmembers (expressed in mole \%) and compositional variables are: $X_{\mathrm{Fe}}=\mathrm{Fe} /(\mathrm{Fe}+\mathrm{Mg}), X_{\mathrm{K}}=\mathrm{K} /(\mathrm{Ca}+\mathrm{Na}+\mathrm{K}), X_{\mathrm{Na}}=\mathrm{Na} /(\mathrm{Ca}+\mathrm{Na}+\mathrm{K})$; epidote, $\mathrm{Ep}=\mathrm{Fe}^{3+} /\left(\mathrm{Fe}^{3+}+\mathrm{Al}-2\right) ;$ almandine, $\mathrm{Alm}=\mathrm{Fe} /(\mathrm{Fe}+\mathrm{Mg}+\mathrm{Ca}+\mathrm{Mn})$, pyrope, $\operatorname{Prp}=\mathrm{Mg} /(\mathrm{Fe}+\mathrm{Mg}+\mathrm{Ca}+\mathrm{Mn})$, grossular, $\mathrm{Grs}=\mathrm{Ca} /(\mathrm{Fe}+\mathrm{Mg}+\mathrm{Ca}+\mathrm{Mn})$, spessartine, $\mathrm{Sps}=\mathrm{Mn} /(\mathrm{Fe}+\mathrm{Mg}+\mathrm{Ca}+\mathrm{Mn})$, ilmenite, $\mathrm{Ilm}=$ $\mathrm{Fe} /(\mathrm{Fe}+\mathrm{Mg}+\mathrm{Mn}) ;$ anorthite, $\mathrm{An}=\mathrm{Ca} /(\mathrm{Ca}+\mathrm{Na}+\mathrm{K}) ;$ pfu: per formula unit.

Three micaschist samples (LH1B, LH3, LH16) and one sample of a garnet-grunerite-bearing gneiss (LH9) come from a small area $\left(\sim 500 \mathrm{~m}^{2}\right.$; star 1 in Figure $\left.1 \mathrm{~b}\right)$ of the "Balatg window", underlying the orthogneiss. The micaschist samples LH1B, LH3 and LH16 display similar petrographic and microstructural features. Alternating quartz \pm plagioclase- and mica-rich layers are parallel to the preferred orientation of muscovite and biotite and define the first schistosity, S1. This schistosity is folded by tight to isoclinal mostly rootless folds. The main regional schistosity S2 developed in the axial plane of the folds (Figure 4a) and is marked by the preferred orientation of muscovite and biotite and wraps around porphyroblasts of andalusite and garnet (LH16). Garnet is rare and generally forms small crystals (max. $1 \mathrm{~mm}$ ), with the exception of sample LH16, where both small and large (up to $7 \mathrm{~mm}$ ) crystals are present. Biotite $\left(X_{\mathrm{Fe}}=0.57-0.61, \mathrm{Ti}=0.07-0.17 \mathrm{pfu}\right)$ and muscovite $\left(\mathrm{X}_{\mathrm{Na}}=0.10-0.13, \mathrm{Si}=3.00-3.09 \mathrm{pfu}\right)$ have the same composition regardless of the textural position. Matrix plagioclase contains $27-33 \%$ anorthite. Accessory minerals include ilmenite (IIm9092), apatite, tourmaline, monazite, pyrite (LH1B), zincian spinel (LH3; 64-69\% gahnite, $24-29 \%$ hercynite), and chlorite ( $\left.X_{\mathrm{Fe}}=0.55-0.59\right)$ locally replacing biotite. Anhedral porphyroblasts of andalusite (up to $10 \mathrm{~mm}$ ) are preferentially localized in mica-rich layers. When these layers are folded, andalusite is occasionally S-shaped, but displays only a weak or no undulose extinction. The folded S1 is also preserved in andalusite as curved inclusions of biotite and ilmenite (Figure 4b). S2 wraps around, but is also preserved in andalusite as inclusions of biotite, the size of which increases from core to rim $(0.25 \rightarrow 0.75 \mathrm{~mm}$; Figure $4 \mathrm{c})$. Andalusite includes anhedral staurolite (up to $2 \mathrm{~mm}$; $X_{\mathrm{Fe}}=0.85-0.89$ ) and garnet (up to $0.5 \mathrm{~mm}$; Figure $4 \mathrm{~b}$ ). Staurolite may contain oriented ilmenite inclusions that define an internal fabric (S1) at high angle to the external S2 (Figure 4d).

This article is protected by copyright. All rights reserved. 
In sample LH16, garnet forms large (up to $7 \mathrm{~mm}$ ) subhedral porphyroblasts commonly surrounded by biotite (Figure 4e), and small crystals $(0.2 \mathrm{~mm})$ included in staurolite. Large garnet contains numerous unidentified micrometric inclusions and larger inclusions ( $\sim .1 \mathrm{~mm})$ of muscovite $\left(X_{\mathrm{Na}}=0.06-0.18\right)$, quartz, plagioclase (An20-25) and epidote (Ep35-67) that define a sigmoidal internal foliation (S1) oriented at high angle to the matrix S2 (Figure 4e). Some epidote crystals contain LREE and have the composition of allanite $(\mathrm{Ca}=1.51-1.94 \mathrm{pfu})$. Biotite is absent from the garnet core and appears in its rim. Garnet is chemically zoned (Figure 5a). A large core ( $\sim \mathrm{mm})$ is characterized by a relatively homogeneous grossular content (Grs19-23) and $X_{\mathrm{Fe}}(0.92-0.94)$ and a rimward decreasing content of spessartine (Sps14 $\rightarrow 11)$. A rim $(<1 \mathrm{~mm})$ displays a strong decrease in grossular (Grs19-23 $\rightarrow 10$ ), and further decrease in spessartine (Sps11 $\rightarrow 8$, the lowermost values were collected manually off the automatic profile presented) and $X_{\mathrm{Fe}}(0.92 \rightarrow 0.90)$. The outermost rim $(\sim 100 \mu \mathrm{m})$ displays a sharp increase of spessartine (Sps8 $\rightarrow 17)$, accompanied by a continuing decrease of $X_{\mathrm{Fe}}(0.90 \rightarrow 0.87)$ and grossular (Grs10 $\left.\rightarrow 7\right)$. Small garnets, chemically similar to the rim of the large crystals $\left(X_{\mathrm{Fe}}=0.89 ;\right.$ Grs11-12; Sps8), are systematically separated from the staurolite host by a corona of andalusite, which is in optical continuity with andalusite surrounding the staurolite relic. Unlike allanite, only present as inclusions in garnet, monazite is absent from garnet and exclusively present in the rock matrix, or as inclusions in staurolite and andalusite.

In samples LH1B and LH3, garnet forms small (max. $1 \mathrm{~mm}$ ) crystals in the matrix. They are optically zoned with an anhedral embayed greyish "cloudy" core (g1) and a clear euhedral to anhedral rim (g2; Figures $4 \mathrm{f}$ and $5 \mathrm{~b}$ ). Chemical zoning is subtle but systematic. Cores display a weak increase of spessartine and $X_{\mathrm{Fe}}$ towards the core-rim interface $\left(X_{\mathrm{Fe}}=0.89 \rightarrow 0.91\right.$, Sps $\left.21 \rightarrow 22, \mathrm{Grs} 7-6\right)$. Rims are poorer in grossular and also display an increase of spessartine and $X_{\mathrm{Fe}}$ towards the outer $\operatorname{rim}\left(X_{\mathrm{Fe}}=0.90 \rightarrow 0.93\right.$, Sps21 $\rightarrow 24$, Grs4; Figure $\left.5 b\right)$. Outermost rims locally contain up to $32 \%$ spessartine (LH3).

This article is protected by copyright. All rights reserved. 
The garnet-grunerite-bearing gneiss sample LH9 displays an irregular poorly developed schistosity marked by the alignment of biotite (up to $0.5 \mathrm{~mm} ; X_{\mathrm{Fe}}=0.57-0.63, \mathrm{Ti}=0.07-0.09 \mathrm{pfu}$ ). It wraps around abundant large (up to $5 \mathrm{~mm}$ ) anhedral crystals of garnet, and smaller crystals of polysynthetically twinned grunerite (up to $1 \mathrm{~mm} ; X_{\mathrm{Fe}}=0.59-0.61, \mathrm{Ca}+\mathrm{Na}(\mathrm{B})=0.1-0.3 \mathrm{pfu}, \mathrm{Si}=7.9 \mathrm{pfu}$; Figure 4g). The sample matrix contains abundant quartz, epidote (Ep03-09), ilmenite, apatite, and minor muscovite $\left(\mathrm{X}_{\mathrm{Na}}=0.01-0.06 ; \mathrm{Si}=3.04-3.09 \mathrm{pfu}\right)$ and chlorite. Garnet is anhedral, poikilitic and contains sigmoidal inclusions of epidote (Ep30-46), quartz, apatite, ilmenite, and minor muscovite $\left(\mathrm{X}_{\mathrm{Na}}=0.02-0.03 ; \mathrm{Si}=3.05-3.09 \mathrm{pfu}\right)$, plagioclase $(\mathrm{An01}-05)$ and biotite (Figure 4h). Epidote is concentrated in garnet core and the mode strongly decreases towards the rim. Chemical zoning of garnet is marked by a rimward decrease of $X_{\mathrm{Fe}}(0.96 \rightarrow 0.89)$, spessartine (Sps9 $\left.\rightarrow 1\right)$ and grossular (Grs24 $\rightarrow 17$ ). The outermost rim is locally marked by a slight increase in spessartine (Sps5). Both garnet and grunerite are coated by coarse and poorly oriented crystals of biotite (up to $0.5 \mathrm{~mm}$; Figure $4 \mathrm{~g}, \mathrm{~h}$ ) and minor chlorite.

These observations can be interpreted in terms of two syntectonic metamorphic events. In the micaschists, the early development of S1 was associated with the crystallization of the large garnet crystals with sigmoidal inclusions. The main characteristic of the garnet is a continuous rimward decrease of $X_{\mathrm{Fe}}$, Sps and Grs, typical of prograde growth zoning. The increase of spessartine in the outermost rim is interpretable in terms of partial resorption of garnet. However, it is associated with a decrease of $X_{\mathrm{Fe}}$, suggesting that resorption occurred along a prograde (heating) $P-$ $T$ path. This prograde growth started in the stability field of epidote, exclusively preserved as inclusions in large garnet, continued during the appearance of biotite included in the garnet rim, and peaked in the stability field of staurolite (stage M1). The "cloudy" cores of the small garnets (g1) are inferred to also belong to this metamorphic stage. Their anhedral shape and the slight increase of spessartine towards the interface with garnet 2 (i.e. the g1-g2 interface; Figure $5 b$ ) is interpreted in terms of partial resorption of garnet 1 prior to a renewed growth of garnet (g2). The increase of spessartine in the outermost rim of garnet 2 is attributable to a final stage of partial resorption. The

This article is protected by copyright. All rights reserved. 
second metamorphic stage M2 is associated with the development of the main schistosity S2, marked by the crystallization of andalusite as well as the second generation of garnet (g2).

Muscovite, plagioclase, quartz and ilmenite were stable during the whole metamorphic history.

In the garnet-grunerite-bearing gneiss, the first event (M1) is characterized by a syn-S1 crystallization of garnet, grunerite and minor plagioclase. The subsequent event (M2) was coeval with S2 and caused partial resorption, and replacement of garnet and grunerite by biotite. Biotite, ilmenite, quartz and minor muscovite are inferred to be stable during all the metamorphic history of the rock. Epidote seems to crystallize in two episodes, at the beginning of $M 1$ and during $M 2$, whereas the peak-M1 assemblage may be epidote-free. Minor chlorite either belongs to $M 2$, or develops late, at the expense of biotite.

\section{$5 \quad P-T$ ESTIMATES}

\subsection{Methods}

$P-T$ pseudosections were calculated in the model system MnNCKFMASHTO using THERMOCALC (Powell \& Holland, 1988) and Theriak/Domino (de Capitani \& Brown, 1987; de Capitani \& Petrakakis, 2010) and the thermodynamic data set 5.5 (Holland \& Powell, 1998); updated November 2003; translation for Theriak/Domino by Tinkham, 2012 - http://dtinkham.net/peq.html). The solution phases considered in the calculations, and the activity-composition models used are amphibole (Diener \& Powell, 2012), chlorite (Le Bayon, Pitra, Ballèvre, \& Bohn, 2006; based on Holland, Baker, \& Powell, 1998), chloritoid, cordierite, epidote, staurolite (Holland \& Powell, 1998), garnet, biotite, ilmenite, hematite (White, Pomroy, \& Powell, 2005), magnetite (White, Powell, Holland, \& Worley, 2000), plagioclase (Holland \& Powell, 2003); muscovite, paragonite (Coggon \& Holland, 2002) and margarite (margarite-paragonite mixing on sites, neglecting muscovite, $W(\mathrm{ma}, \mathrm{pa})=14.5 \mathrm{~kJ}(\mathrm{AX}$ notes, Powell \& Holland, 2002), DQF for paragonite set to $5 \mathrm{~kJ}$ to fit natural data of Höck, 1974 and Feenstra, 1996).

This article is protected by copyright. All rights reserved. 
Bulk compositions used for the calculations were obtained by the area-scan method at SEMEDS (JSM-7100 F scanning electron microscope, CMEBA, University Rennes 1) on parts of thin sections estimated to approach an equilibration volume. Due to the heterogeneous nature of the samples (presence of porphyroblasts or layering) analyses were performed using various area sizes and the results checked for robustness. The bulk compositions used are indicated as insets in the diagrams in mole per cent normalized to $100 \%$. Additionally, although all the samples contain ilmenite and lack magnetite, which suggests relatively low amounts of $\mathrm{Fe}^{3+}$ (Connolly \& Cesare, 1993), the effects of varying $\mathrm{Fe}^{3+}$ were investigated in $P / T-X\left(\mathrm{Fe}^{3+}\right)$ pseudosections. Three samples contain apatite and one of them pyrite. The bulk compositions were corrected accordingly. The fluid phase was fixed as pure $\mathrm{H}_{2} \mathrm{O}$ and considered in excess in the calculations.

\subsection{Sample LH16}

First, two $P-T$ pseudosections were calculated using both THERMOCALC and Theriak/Domino for a bulk composition measured over an area of $1.5 \times 2 \mathrm{~cm}$ that comprises garnet, epidote, andalusite, staurolite as well as the matrix. The proportion of $\mathrm{Fe}^{3+}$ was arbitrarily set to $5 \%$ of the total Fe. The only significant difference between these diagrams is the appearance of chloritoid at $P<2 \mathrm{kbar}$ and $T<510^{\circ} \mathrm{C}$ on the pseudosection calculated with Theriak/Domino with respect to the one calculated with THERMOCALC (Figure S2). Otherwise, the two diagrams are virtually identical, the relative position of the fields being the same, and the differences in the absolute position of the lines being less than $5^{\circ} \mathrm{C}$ and $0.1 \mathrm{kbar}$. Because the computations with Theriak/Domino are significantly less time-consuming than with THERMOCALC, subsequent calculations were carried out using only Theriak/Domino.

In these diagrams, magnetite is stable across a large domain at $P<7 \mathrm{kbar}$, but is lacking in our samples. Consequently, a $P-X\left(\mathrm{Fe}^{3+}\right)$ pseudosection has been calculated at $T=580^{\circ} \mathrm{C}$ (Figure S3) in order to estimate the influence of the oxidation state of the sample on the stability of the mineral

This article is protected by copyright. All rights reserved. 
assemblages (cf. López-Carmona, Pitra, \& Abati, 2013; White et al., 2000). In the interval $0 \%<X\left(\mathrm{Fe}^{3+}\right.$ ) $<5 \%$, the variation of $X\left(\mathrm{Fe}^{3+}\right)$ only influences the stability of magnetite, ilmenite and rutile, whereas the other minerals only display negligible variations. Magnetite becomes stable for $X\left(\mathrm{Fe}^{3+}\right)$ ratios $(=$ $\mathrm{Fe}^{3+} / \mathrm{Fe}_{\text {tot }}$ ) higher than $3 \%$, and an arbitrary low value of $1 \% \mathrm{Fe}^{3+}$ was used for the subsequent calculations.

The resulting $P-T$ pseudosection (Figure 6) was contoured with compositional isopleths for garnet $\left(X_{\mathrm{Fe}}, \mathrm{Grs}, \mathrm{Sps}\right)$ in order to infer the conditions of crystallization of the epidote-bearing garnet core. In the $P-T$ space investigated, epidote is stable at $T<510^{\circ} \mathrm{C}$ and $P>3 \mathrm{kbar}$. The isopleths corresponding to the composition of the garnet core $\left(X_{\mathrm{Fe}}=0.94, \mathrm{Grs} 23, \mathrm{Sps} 14\right)$ intersect in the field ma-pl-chl $(+\mathrm{g}, \mathrm{mu}, \mathrm{q}, \mathrm{ilm})$ around $520^{\circ} \mathrm{C}, 5.5 \mathrm{kbar}$, just outside the epidote-bearing domain. This point is discussed later. Subsequent slight rimward decrease of spessartine and sub-constant grossular content suggest a limited prograde up-pressure evolution, parallel to the Grs isopleths, during the growth of the garnet core.

Garnet represents $\sim 20 \%$ of the surface of the domain considered in the previous calculation, and has a large, mostly homogeneous, core and zoned rims (see above). In order to model the crystallization of the assemblage in equilibrium with the garnet rim (M1 peak), the garnet core ( $15 \%$ of the domain) has been subtracted from the bulk composition of the domain.

With respect to Figure 6, the pseudosection calculated for this modified bulk-composition (Figure 7) shows a reduced stability domain of margarite and a larger stability domain for staurolite. The diagram has been contoured with compositional isopleths for garnet ( $X_{\mathrm{Fe}}, \mathrm{Grs}, \mathrm{Sps}$ ) as well as staurolite $\left(X_{\mathrm{Fe}}\right)$ and muscovite $\left(X_{\mathrm{Na}}\right)$. The isopleths corresponding to the core/rim transition $\left(X_{\mathrm{Fe}}\right.$ $\sim 0.92, \mathrm{Grs} \sim 20, \mathrm{Sps}^{\sim 11}$ ) intersect around $6-7 \mathrm{kbar} 550{ }^{\circ} \mathrm{C}$. The rim zoning, characterized by a significant decrease of grossular associated with a slight decrease of $X_{\mathrm{Fe}}$ and spessartine, corresponds to decreasing pressure and increasing temperature. The subsequent increase of spessartine in the outermost rim is interpretable in terms of partial resorption and reequilibration of

This article is protected by copyright. All rights reserved. 
garnet during continuous heating and decreasing pressure in the field of staurolite. The inferred peak M1 association staurolite, garnet, biotite (+ muscovite, plagioclase, ilmenite and quartz) corresponds to the field st-bi-pl $(+\mathrm{g}, \mathrm{mu}, \mathrm{q}, \mathrm{ilm})$ at 3-7 kbar and $550-640^{\circ} \mathrm{C}$. The observed compositions of staurolite $\left(\mathrm{X}_{\mathrm{Fe}}=0.88-0.89\right)$ and garnet $\left(\mathrm{X}_{\mathrm{Fe}}=0.87\right.$, Sps17, Grs7) compared to the position of the corresponding isopleths (Figure 7) suggest $4-5 \mathrm{kbar}$ and $580^{\circ} \mathrm{C}$ for the peak of the M1 stage.

The association andalusite, garnet, biotite, muscovite, plagioclase and quartz, representative of the M2 stage, corresponds to the field and-bi-pl spanning 1-4 kbar and $510-640{ }^{\circ} \mathrm{C}$. Compositional isopleths indicate that muscovite becomes less paragonitic toward high temperatures in the andalusite field (Figure 7c). Values in agreement with the measured composition $\left(\mathrm{X}_{\mathrm{Na}}=0.10-0.13\right)$ are found in the high temperature part of the andalusite field around $580-620^{\circ} \mathrm{C}$.

\subsection{Sample LH1B}

The chemical composition used to calculate the first $P-T$ pseudosection for this sample (Figure 8) has been calculated using a SEM-measured composition of an area of $\sim 1.2 \mathrm{~cm}^{2}$ that comprises staurolite, garnet 1 and 2, andalusite and a large proportion of matrix. One of the remarkable features of the diagram is the stability of garnet, reduced to $T>\sim 500{ }^{\circ} \mathrm{C}$ and $P>\sim 3 \mathrm{kbar}$. The peak $\mathrm{M} 1$ association staurolite, garnet, biotite, muscovite, plagioclase, quartz, ilmenite is modelled in the field g-bi-st-pl (+ mu, q, ilm) between $540-650^{\circ} \mathrm{C}$ and 3-7 kbar. The $\mathrm{M} 2$ assemblage is interpreted to contain andalusite, biotite and plagioclase $(+\mathrm{mu}, \mathrm{q}, \mathrm{ilm})$ in equilibrium with the clear garnet 2 overgrowths on garnet 1 "cloudy" cores. This assemblage is modelled in the narrow field and-g-bi-pl at 530-600 ${ }^{\circ} \mathrm{C}, 3-4 \mathrm{kbar}$, in the uppermost part of the andalusite stability domain.

Given the low mode of garnet in the rock, and the possible dependence of its stability on the choice of the effective bulk composition, another $P-T$ pseudosection has been calculated using the

This article is protected by copyright. All rights reserved. 
SEM-measured composition of a smaller area $\left(0.15 \mathrm{~cm}^{2}\right)$ included in the previously analysed region, in order to explore the crystallization of garnet 2. This area comprises garnet, andalusite, biotite, muscovite, plagioclase, quartz and ilmenite, and contains a comparatively larger proportion of garnet. Additionally, the relics of garnet 1 (the anhedral "cloudy" cores) have been removed from the bulk composition. This diagram (Figure 9) is contoured with compositional isopleths for garnet and muscovite, as well as the mode isopleths for garnet. With respect to Figure 8 , the stability field of garnet is significantly increased and that of staurolite decreased. The paragenesis garnet, andalusite, biotite, muscovite, plagioclase, quartz, ilmenite is modelled in a field between $540-640{ }^{\circ} \mathrm{C}$ and 1.5-4 kbar. Isopleths corresponding to the composition of garnet $2\left(X_{\mathrm{Fe}}=0.90, \mathrm{Sps} 21, \mathrm{Grs} 4\right)$ indicate equilibration at $\sim 3 \mathrm{kbar}, 570^{\circ} \mathrm{C}$, whereas the observed $\mathrm{X}_{\mathrm{Na}}$ of muscovite $(0.10-0.13)$ suggests slightly higher temperatures $\left(580-620^{\circ} \mathrm{C}\right)$.

The isopleths of garnet mode have a steep negative slope at low temperatures, in the chlorite-present fields, and a flat positive slope at low pressures and high temperatures, in the fields with aluminium silicates or staurolite (Figure 9a). In this framework, the inferred two-stage growth of garnet, interrupted by a period of garnet resorption (cf. above) can be interpreted. Garnet 1 growth is compatible with a prograde $P-T$ path peaking in the g-st-bi-pl field (M1). Subsequent partial resorption requires an evolution involving cooling and/or decompression. The growth of garnet 2, peaking in the field g-pl-bi-and (M2), might involve renewed heating, possibly associated with moderate pressure increase. Alternatively, garnet 2 could grow during cooling in the g-pl-bi-and field. This point is discussed later.

\subsection{Sample LH3}

$P-T$ pseudosections have been calculated for a bulk composition measured over a small area $(0.15$ $\mathrm{cm}^{2}$ ) that includes garnet, staurolite, andalusite, biotite, muscovite, plagioclase, quartz and ilmenite. The diagram has been contoured with compositional isopleths for staurolite and muscovite as well as mode isopleths for garnet (Figure 10). The peak M1 association staurolite, garnet, biotite,

This article is protected by copyright. All rights reserved. 
muscovite, plagioclase, quartz, ilmenite is modelled in the field g-st-pl-ilm between 3-7 kbar and $550-650^{\circ} \mathrm{C}$. The measured composition of staurolite $\left(\mathrm{X}_{\mathrm{Fe}}=0.86-0.87\right)$ indicates equilibration around 5-6 kbar and $590-640{ }^{\circ} \mathrm{C}$. The $\mathrm{M} 2$ association garnet 2 , andalusite, biotite, muscovite, plagioclase, quartz, ilmenite corresponds to the g-pl-and-ilm field and indicates equilibration at $520-620^{\circ} \mathrm{C}, 2-4$ kbar. Removing garnet core (corresponding to garnet 1 ) from the measured composition does not introduce major modifications in the pseudosection, except that the garnet-out line is shifted toward higher pressures ( $\sim .5 \mathrm{kbar}$, dashed line in the g-pl-and-ilm field; Figure 10).

\subsection{Sample LH9 - Garnet-grunerite-bearing gneiss}

The diagrams for this sample are shown in the supplementary material (Figure S4). They are calculated for the bulk composition measured over a small area $\left(0.9 \mathrm{~cm}^{2}\right)$ of the thin section considered as representative of the mineralogical composition of the sample. This area comprises grunerite, garnet, epidote, biotite, muscovite, ilmenite and quartz. The $X\left(\mathrm{Fe}^{3+}\right)$ ratio was set to $2 \%$, following the exploration of a range of $P / T-X\left(\mathrm{Fe}^{3+}\right)$ pseudosections. In the resulting $P-T$ pseudosection (Figure S4), biotite, quartz and ilmenite are stable over the whole $P-T$ range modelled. Garnet is stable in most fields with the exception of those at $T<485{ }^{\circ} \mathrm{C}$ at $P<\sim 8 \mathrm{kbar}$. FeMg clinoamphibole (cummingtonite-grunerite) is stable in the HP-LT part of the diagram $(P>4 \mathrm{kbar}$, $\left.T<560^{\circ} \mathrm{C}\right)$, epidote and chlorite in the $\mathrm{LT}\left(T<530^{\circ} \mathrm{C}\right.$ and $550^{\circ} \mathrm{C}$, respectively) and plagioclase in the LP and HT part of the diagram. Orthoamphibole, not present in our samples, is stable in the LP-HT part of the diagram $\left(550-650^{\circ} \mathrm{C}, 1-6.5 \mathrm{kbar}\right)$. Plagioclase and clinoamphibole are stable together only along a chaplet of small fields between 4-6 kbar and $490-560{ }^{\circ} \mathrm{C}$ (Figure S4), but none of them contains the complete inferred M1 paragenesis, comprising garnet, grunerite, epidote, biotite, plagioclase, muscovite, ilmenite and quartz. Despite the ubiquitous presence of chlorite, not observed in the M1 assemblage, it can be tentatively inferred, to first order, that garnet crystallization started in the field pl-chl-mu-ep (+ g, bi, ilm, q) at $480-510^{\circ} \mathrm{C}, 3-6 \mathrm{kbar}$. The $P-T$ evolution followed up pressure, up temperature to the field camp-chl-mu $(+\mathrm{g}, \mathrm{bi}, \mathrm{ilm}, \mathrm{q})$ at $530-$

This article is protected by copyright. All rights reserved. 
$550{ }^{\circ} \mathrm{C}, 5.5-6$ kbar. The $\mathrm{M} 2$ association epidote, biotite, muscovite, ilmenite, quartz \pm chlorite, garnet) is not successfully modelled in the pseudosection either, since plagioclase (or albite), inferred not to be part of $\mathrm{M} 2$, is always present. Varying the $X\left(\mathrm{Fe}^{3+}\right)$ ratio does not improve the results.

\section{GEOCHRONOLOGY}

Two metamorphic stages, associated with different regional structures, were identified in the Canigou metapelites. In order to set the tectono-metamorphic evolution in a temporal framework, an attempt was made to date some of the allanite and monazite grains found in sample LH16 in distinct textural positions. Unfortunately, the allanite grains were too small and too thin to get any meaningful data.

\subsection{Analytical procedure}

Suitable minerals for $\mathrm{U}-\mathrm{Th}-\mathrm{Pb}$ dating were identified using a petrological microscope and imaged using backscattered electron microscopy (BSE; CMEBA, Université Rennes 1, France). U-Th-Pb in-situ monazite dating was performed 'in context' directly in thin sections at Géosciences Rennes using an ESI NWR193UC Excimer laser system coupled to an Agilent 7700x Q-ICP-MS, and consisted of $7 \mu \mathrm{m}$ ablation spots with repetition rates of $2 \mathrm{~Hz}$.

Raw data were corrected for $\mathrm{Pb} / \mathrm{U}$ and $\mathrm{Pb} / \mathrm{Th}$ laser-induced elemental fractionation and for instrumental mass discrimination by standard bracketing with repeated measurements of the Moacir monazite standard (Gasquet et al., 2010). With the samples, the Manangoutry monazite standard (c. $555 \mathrm{Ma}$; Paquette \& Tiepolo 2007; $556.5 \pm 3.9 \mathrm{Ma}(\mathrm{N}=7), \mathrm{MSWD}=0.99)$ was measured as unknowns to monitor the precision and accuracy of the analyses. For more information on the procedures, see Ballouard et al. (2015). Operating conditions are given in Table S2.

Data reduction was carried out with the GLITTER ${ }^{\circledR}$ software package developed by the Macquarie Research Ltd. (Van Achterbergh, Ryan, \& Griffin, 2001). Concordia ages and diagrams

This article is protected by copyright. All rights reserved. 
were generated using Isoplot/Ex (Ludwig, 2012). All errors given in Table 2 are listed at one sigma, but where data are combined for regression analysis or to calculate weighted means, the final results are provided with $95 \%$ confidence limits.

\subsection{U-Th-Pb dating}

Monazite is found as small crystals $(\sim 30 \mu \mathrm{m})$ either in the matrix or as inclusions in biotite, andalusite as well as along cracks in staurolite. These monazite grains show a slight patchy zoning (inset in Figure 11). Twenty-four analyses were performed on ten monazite crystals in every textural position. The Th/ $\mathrm{U}$ ratios of these grains vary between 7.1-10.9 in andalusite $(\mathrm{N}=12), 4.5-6.8$ in staurolite $(\mathrm{N}=4)$ and 4.3-7.9 in biotite $(\mathrm{N}=8)$ except for one inclusion in biotite with a significantly lower value $(\mathrm{Th} / \mathrm{U}=0.2)$. Plotted in a ${ }^{206} \mathrm{~Pb} /{ }^{238} \mathrm{U}$ versus ${ }^{208} \mathrm{~Pb} /{ }^{232} \mathrm{Th}$ Concordia diagram, a cluster of seventeen out of the twenty-four analyses (plain black ellipses, Figure 11), regardless of their textural position, yields a concordant age of $300.0 \pm 1.4 \mathrm{Ma}$ (Figure 11, MSWD $=0.85$ ). Six other analyses yield older or younger dates (dashed ellipses, Figure 11). Three older apparent ages plot between c. 317-305 Ma, with one having a very concordant apparent age and distinctive $\mathrm{Th} / \mathrm{U}$ (c. $317 \mathrm{Ma} ; \mathrm{Th} / \mathrm{U}=0.2$ ). The last and older apparent age plot at c. $330 \mathrm{Ma}$ (long-dashed ellipse, Figure 11).

\section{DISCUSSION}

\section{1 $\quad P-T$ conditions}

Both the micaschists and the garnet-grunerite gneiss have been gathered in a small area within the same tectonic unit, and must have consequently undergone the same metamorphic history and broadly the same $P-T$ conditions. In the micaschists, this is supported by the presence of the same key minerals in identical microstructural positions: staurolite for $\mathrm{M} 1$ and andalusite for $\mathrm{M} 2$. This can be used to further constrain the $P-T$ evolution.

The first metamorphic event (M1) peaks with assemblages containing staurolite, garnet,

This article is protected by copyright. All rights reserved. 
biotite, muscovite, plagioclase quartz and ilmenite. The $P-T$ conditions estimated from the different micaschist samples (LH1B: 3-7 kbar, 540-650 ${ }^{\circ} \mathrm{C}$; LH3: 5-6 kbar, 590-630 ${ }^{\circ} \mathrm{C}$; LH16: 4-5 kbar, $580^{\circ} \mathrm{C}$ ) suggest M1 peak $T$ conditions of $\sim 5 \mathrm{kbar}, 600^{\circ} \mathrm{C}$. This M1 peak is the thermal culmination of a prograde evolution evidenced by the inclusions of epidote, progressive appearance of biotite and chemical zoning in garnet (sample LH16), and that passed through a pressure peak at 6-7 kbar, 550 ${ }^{\circ} \mathrm{C}$.

The observation that the isopleths corresponding to the composition of the garnet core (LH16) only intersect at slightly higher temperature than the stability domain of epidote (around 520 ${ }^{\circ} \mathrm{C}$ and $5.5 \mathrm{kbar}$, Figure 6) can be related to overstepping of the garnet-in reaction and subsequent fast crystallization in a metastable epidote-bearing matrix, or to later partial diffusional reequilibration of the composition of the garnet core, or to modelling uncertainties. These may include uncertainties in the estimation of the effective bulk composition, including, but not limited to, the $X\left(\mathrm{Fe}^{3+}\right)$ ratio, and also imperfections in the thermodynamic data and activity-composition relations. Textural and chemical evidence suggest subsequent partial resorption of garnet (outermost rim of large garnet and g1/g2 interface in small garnet), prior to the second metamorphic stage M2. This is compatible with a temperature and/or pressure decrease (Figures 9a and 10b)

The second metamorphic stage (M2) is characterized by the stability of andalusite. The overlap of the M2 $P-T$ conditions (based on the composition of garnet 2 and muscovite) from the different samples, yields $P-T$ conditions of $\sim 2-3$ kbar, $550-600{ }^{\circ} \mathrm{C}$ for this metamorphic stage (Figure 9). The whole metamorphic evolution could then be interpreted in terms of a simple clockwise $P-T$ path (arrow 1, Figure 9). However, the growth of garnet 2 around partly resorbed garnet 1 possibly suggests a period of heating following decompression and cooling (arrow 2, Figure 9), pointing to a two-stage evolution.

The results from the micaschists are difficult to reconcile with those for the garnet-grunerite

This article is protected by copyright. All rights reserved. 
gneiss. In the latter, none of the fields modelled correspond to either the M1 or the M2 assemblage. The $P-T$ conditions from the micaschists point to domains in the pseudosection without Fe-Mg clinoamphibole (grunerite) and with orthoamphibole, which was not observed in the sample. Clinoamphibole and epidote are modelled to be stable at temperatures lower by $\sim 75^{\circ} \mathrm{C}$ and $\sim 50{ }^{\circ} \mathrm{C}$, respectively. The reasons for this misfit are probably related to the imperfections of the existing activity-composition relations for Fe-Mg clino- and orthoamphibole.

\subsection{Simple $\boldsymbol{P}-\boldsymbol{T}$ loop or polymetamorphism?}

The key to this crucial question lies in the interpretation of the garnet 2 overgrowths on garnet 1 . In order to allow garnet growth, the $P-T$ path has to cross the isopleths of garnet mode in the sense of increasing proportion of garnet. Given the orientation of these isopleths, this can easily be achieved only along a prograde $P-T$ path in the field g-pl-chl (Figure 9, arrow 2). A continuous heating in the andalusite-bearing fields would lead to only slightly resorbing the newly formed garnet 2 , or to keeping its proportion constant if heating was associated with a slight pressure increase.

A retrograde $P-T$ path in the g-pl-and field, following decompression from the M1 stage, could theoretically produce similar features (Figure 9a, arrow 1). However, retrograde growth of garnet appears to be uncommon, being rarely reported in the literature (e.g. Korhonen, Brown, Clark, \& Bhattacharya, 2013). Furthermore, three first-order observations point to the growth of the M2 andalusite-bearing assemblage along a prograde $P-T$ path. (1) The size of biotite inclusions increases from the core to the rim of andalusite (Figure 4c). (2) In the andalusite stability field, the proportion of andalusite increases at the expense of muscovite with increasing temperature.

Consequently, if garnet 2 crystallized during cooling, a concomitant replacement of andalusite by muscovite would be expected, but is not observed. (3) The growth of sillimanite (locally prismatic) at the expense of andalusite was reported in micaschists from the sillimanite zone in the north-western part of the "Balatg window" (Gibson, 1992; Guitard et al., 1998). Similar features are observed in sample BLB1457 collected in the sillimanite zone in the south-westernmost Balatg micaschists

This article is protected by copyright. All rights reserved. 
(Figure 1, star 3; Figure 12a). Consequently, it is suggested that M1 and M2 do not correspond to two stages of a simple clockwise metamorphic $P-T$ loop, but rather to two prograde metamorphic (and deformational) events separated by a period of exhumation and cooling (Figure 9a, arrow 2). Interestingly, Laumonier, Marignac, \& Kister (2010), using general regional considerations, proposed a similar scenario.

\subsection{Geochronology}

In sample LH16, garnet crystallized along a prograde $P-T$ path at temperatures ranging between 520 and $600{ }^{\circ} \mathrm{C}$. It contains inclusions of allanite, the quantity of which strongly decreases in the garnet rims. Monazite is never found in garnet and only occurs as inclusions in either biotite, staurolite or andalusite that crystallized at temperatures reaching up to $\sim 600^{\circ} \mathrm{C}$. This suggests metamorphic crystallization of monazite at the expense of allanite close to the peak of the prograde metamorphism M1. This appears to be a common feature in metapelitic rocks with increasing temperature in a similar $P-T$ range. This typically happens near the staurolite (Smith \& Barreiro, 1990; Spear \& Pyle, 2002) or biotite isograds depending on the whole rock composition, and more particularly on the calcium and aluminium contents (Spear, 2010; Wing, Ferry, \& Harrison, 2003). According to empiric determination of the allanite/monazite transition in metapelitic rocks (Wing et al., 2003), the crystallization of monazite in our sample $\left(\mathrm{Ca} / \mathrm{Ca}_{\text {shaw }}=0.90\right.$ and $\mathrm{Al} / \mathrm{Al}$ shaw $=1.20$; calculated with respect to the average pelite composition defined by Shaw, 1956) occurred at a temperature close to the biotite isograd $\left(\sim 550^{\circ} \mathrm{C}\right.$; i.e. close to the peak pressure during the M1 event in Figures 7 and 13).

Consequently, the easiest interpretation of the geochronological data would be that the $c$. $300 \mathrm{Ma}$ age corresponds to the crystallization of monazite near the pressure peak of the M1 metamorphic event. The two younger dates can then be attributed to a slight lead loss. The four older apparent ages could be the result of either incorporation of external radiogenic lead during or after the initial crystallization of the monazite crystals, or partial resetting of older (detrital) grains.

This article is protected by copyright. All rights reserved. 
On the other hand, despite the reputedly high closure temperature of its U-Th-Pb system (at least $700{ }^{\circ} \mathrm{C}$; e.g. Cherniak, Watson, Grove, \& Harrison, 2004; Parrish, 1990), monazite is known to recrystallize readily by dissolution/precipitation processes, in particular when fluids are involved (Didier et al., 2013; Tartèse, Ruffet, Poujol, Boulvais, \& Ireland, 2011; Williams, Jercinovic, Harlov, Budzyń, \& Hetherington, 2011). Consequently, the well-defined c. 300 Ma age cluster could correspond to the resetting of the M1 monazite during the dominant M2 LP-HT metamorphism. Inclusions in staurolite and biotite can be easily reset by interaction with fluids along fractures and cleavage planes. The apparent older ages would correspond to partly reset older (detrital) grains, or represent relicts (possibly also partly reset) of the initial crystallization age of the M1 monazite.

Trace element (in particular $\mathrm{Y}$ and Th) zoning of monazite can be used to discriminate different generations of monazite (Kohn, 2016; Kohn, Wieland, Parkinson, \& Upreti, 2005). However, this method commonly yields equivocal results (e.g. Štípská et al., 2015). Furthermore, in the present case, both $\mathrm{M} 1$ and $\mathrm{M} 2$ occur in subsolidus conditions, in assemblages containing garnet, and at similar temperatures. Consequently, they would be expected to bear similar trace element signatures and the detailed mapping of the analysed crystals has not been performed.

On the basis of these considerations, the $c .300 \mathrm{Ma}$ age cannot readily be attributed to the M1 or the M2 metamorphic event. However, an extensive magmatic event associated with LP-HT metamorphism is well documented in the eastern Pyrenees at c. 305-300 Ma (Denèle et al., 2014). Consequently, the c. $300 \mathrm{Ma}$ age most probably corresponds to monazite crystals having crystallized, or recrystallized during the $\mathrm{M} 2 \mathrm{LP}-\mathrm{HT}$ event.

\subsection{Kyanite in the Canigou}

Kyanite has been described in several massifs of the Pyrenees in contrasting textural positions. In the Canigou, kyanite epitaxially intergrown with anhedral crystals of staurolite has been found as inclusion in cordierite and interpreted as a primary mineral (Azambre \& Guitard, 2001). This association is inferred to represent an early medium-pressure event (that might be correlated with

This article is protected by copyright. All rights reserved. 
our M1), preceding a regionally lower-pressure high-temperature event. Conversely, in the Cap de Creus and Albères massifs, kyanite was found as pseudomorphs of andalusite and/or sillimanite and attributed to an increase in pressure during late folding, subsequent to the regional low-pressure metamorphic event (Autran, Fonteilles, \& Guitard, 1966; Autran \& Guitard, 1970; Fonteilles \& Guitard, 1971).

In agreement with the results of thermodynamic modelling, no early (M1) kyanite has been found during this study, although M1 $P-T$ conditions would lead to kyanite crystallization in rocks with the appropriate chemical composition. Yet, in the micaschists overlying the orthogneiss (in the south-eastern part of the dome, Figure 1, star 2), clusters of unoriented kyanite prisms ( $10-100 \mu \mathrm{m})$ were discovered, surrounded by an undeformed corona of white mica (Figure 12b). Such coronas were also found around anhedral crystals of andalusite and interpreted as pseudomorphs thereof. Consequently, this kyanite occurrence is interpreted as a pseudomorph after andalusite, subsequent to the M2 metamorphic event, and possibly related to cooling. Further investigation of this phenomenon is beyond the scope of this study.

\subsection{Tectonic implications}

Three types of tectonic models have been proposed for the Variscan Pyrenees, characterised by gneiss domes, and widespread LP-HT metamorphism and associated magmatism: 1) gravity-driven (diapiric) doming of hot lower crust (e.g. Aguilar et al., 2015; Soula, 1982; Soula, Debat, Deramond, \& Pouget, 1986); 2) lithosphere-scale extension, following or not initial crustal thickening (e.g. Gibson, 1991; Vissers, 1992; Wickham \& Oxburgh, 1986); 3) regional transpression (e.g. Carreras \& Capella, 1994; Cochelin et al., 2017; Denèle, Olivier, Gleizes, \& Barbey, 2009; Druguet, 2001; Gleizes, Leblanc, \& Bouchez, 1998; Mezger, 2009). The latter have progressively evolved from models invoking pure transpression (e.g. Carreras \& Capella, 1994) to those admitting a significant contribution of localised extension (e.g. Cochelin et al., 2017; Mezger \& Passchier, 2003). 
(M1), followed by decompression and cooling, before renewed heating at low pressures (M2). The regionally dominant foliation S2 is associated with the andalusite-bearing $\mathrm{M} 2$ assemblages that typify a LP-HT geothermal gradient. The peak pressure $(6.5 \mathrm{kbar})$ recorded by the metasediments during the M1 stage corresponds to a minimum burial of about $25 \mathrm{~km}$, assuming lithostatic pressure and a mean density of 2.7 g.cm-3 for the metasediments. Given the sedimentary nature of the protoliths, such depths imply burial through subduction or crustal thickening. Relics of subduction zones have not been identified in the Variscan Pyrenees contrary to the other parts of the Variscan belt (e.g. Lardeaux, 2014; Paquette, Ballèvre, Peucat, \& Cornen, 2017; Pin, 1990). The prograde uppressure part of the $P-T$ path is characterized by a cold gradient (of $\sim 9^{\circ} \mathrm{C} / \mathrm{km}$, Figure 7 ), which suggests crustal thickening. Although important, this demonstration is not discriminatory, since most tectonic models (with the exception of Wickham \& Oxburgh, 1986) implicitly or explicitly involve some initial crustal thickening.

The exhumation of the rocks indicated by the pressure decrease between $\mathrm{M} 1$ and $\mathrm{M} 2$ requires crustal thinning by extension and/or erosion (although other mechanisms may be important in other geological settings - e.g. diapiric ascent if rocks have a significant density contrast; e.g. Platt, 1993). Rapid extension and thinning of a previously thickened and thermally relaxed crust would lead to an evolution characterised by a nearly isothermal decompression (arrow 1 in Figure 9; dashed arrow in Figure 13; e.g. Gardien, Lardeaux, Ledru, Allemand, \& Guillot, 1997; Rey, Teyssier, \& Whitney, 2009; Sonder, England, Wernicke, \& Christiansen, 1987). A similar $P-T$ path is characteristic for models involving diapiric ascent of hot material (Aguilar et al., 2015; Lexa et al., 2011). Consequently, such tectonic models can be rejected for the Canigou massif, because this $P-T$ path is not supported by our observations. The alternative $P-T$ evolution, better supported by petrological data, involves a decrease in both pressure and temperature between stages $M 1$ and M2 (arrow 2 in Figure 9, solid arrow in Figure 13; see also Laumonier et al., 2010). Such a $P-T$ path can be attributed to an exhumation driven by significant erosion (albeit possibly combined with some extension) since crustal thickening induces surface elevation and subsequent relief increase

This article is protected by copyright. All rights reserved. 
(Thompson \& England, 1984). It could also be achieved if extension was slow, since $P-T$ paths may be very sensitive to strain rate (Rey et al., 2009).

Tectonic models featuring simple transpression associated with magmatism (Carreras \& Capella, 1994; Carreras \& Druguet, 2014, Denèle et al., 2009, Denèle et al., 2014) fail to account for, or even discuss, the inferred decompression. Furthermore, these models, as well as the similar model of Mezger (2009), and the purely compressive model of Soliva, Salel \& Brunel (1989) associate the regionally dominant foliation in the domes with early thrusting (and implicitly the mediumpressure metamorphism), which is at variance with our observations. Conversely, other tectonic interpretations invoke lateral flow of the lower crust as well as significant, albeit local, extension during regional transpression to explain the rising of the gneiss domes in the Variscan Pyrenees (Cochelin et al., 2017; Mezger \& Passchier, 2003). The decrease of pressure between the M1 and M2 stages may be related to such thickness attenuation of the lower crust after crustal thickening (M1 stage) and depending on the strain rate may be accompanied by cooling.

The subsequent temperature increase (M2) would require an additional heat source. Numerous works have invoked extreme thinning of the lithospheric mantle by either delamination or detachment to explain such additional heat to account for the anomalously hot crust in the Variscan belt in general or specifically in the Pyrenees (Cochelin et al., 2017; Dewey, 1988; Gibson, 1991; Gutiérrez-Alonso et al., 2011; Henk, Blanckenburg, Finger, Schaltegger, \& Zulauf, 2000; Ménard \& Molnar, 1988; Vissers, 1992). The bimodal character of the abundant late Carboniferous magmatism as well as alkaline volcanism during the Permian in the Pyrenees (e.g. Driouch et al., 1989; Kilzi et al., 2016; Lago, Arranz, Pocoví, Galé, \& Gil-Imaz, 2004) support such an interpretation. Although the origin of the mantle thinning remains unclear, it is predicted for and consequently supports tectonic models invoking significant crustal thickening and subsequent extension (e.g. Dewey, 1988; Houseman, McKenzie, \& Molnar, 1981; Ménard \& Molnar, 1988).

The late Carboniferous - Permian period is also marked by the occurrence of continental

This article is protected by copyright. All rights reserved. 
sedimentary basins that are considered to develop during transtensional, rather than transpressional, tectonics in the Variscan Pyrenees (Bixel \& Lucas, 1983; Speksnijder, 1985). The proposed metamorphic evolution (solid arrow, Figure 13), involving a slight pressure increase during the prograde LP metamorphism M2, may be explained by the overburden pressure caused by a significant accumulation of detrital sediments (cf. Martínez, Reche, \& Arboleya, 2001; Pitra \& Guiraud, 1996), later removed by erosion during the Mesozoic. Alternatively, this slight pressure increase may be related to the late crustal shortening invoked to account for the reactivation of previous extensional shear zones into steeply dipping transpressive shear zones, resulting in the amplification of the gneiss domes (e.g. Cochelin et al., 2017). Nevertheless, the timing of the activity of these shear zones, crucial to all the transpressive models, remains a matter of vigorous argument, and could be to a significant degree Alpine rather than Variscan in age (Monié, Soliva, Brunel, \& Maluski, 1994; Vissers, Hinsbergen, Ganerød, \& Wilkinson, 2018; Vissers, Hinsbergen, Wilkinson, \& Ganerød, 2017).

To sum up, after the crustal thickening, our data require a phase of relatively slow crustal thinning. This can be achieved by erosion and/or slow extension or transtension. Tectonic interpretations involving generalized rapid extension, diapiric ascent of the gneiss domes or those suggesting pure transpression do not account for the $P-T$ evolution inferred for the Canigou massif.

The lack of radiometric data in the Canigou massif does not allow to determine the precise timing for the two metamorphic stages, especially the time gap between crustal thickening and subsequent thinning. However, we tentatively propose the following scenario. As noted above most tectonic interpretations of the Variscan Pyrenees involve a phase of crustal thickening that predates the regional ductile deformation coeval with the pervasive LP-HT metamorphism (M2). The Culm sedimentation in the Variscan Pyrenean foreland basin is considered to mark this phase of thickening (Delvolvé, Vachard, \& Souquet, 1998; Engel \& Raymond, 1983). The time span of the Culm sedimentation in the eastern Pyrenees has recently been determined at 330-319 Ma (Martín-

This article is protected by copyright. All rights reserved. 
Closas, Trias, \& Casas Tuset, 2018). As discussed previously, the M2 LP-HT metamorphism most probably developed around c.300 Ma. If true, this leaves a time gap of about $20 \mathrm{Ma}$ between the two phases of metamorphism M1 and M2, allowing for the thermal relaxation of the thickened crust and its subsequent lateral flow.

\section{CONCLUSIONS}

Two syntectonic metamorphic stages have been recognized in the metapelites underlying the orthogneiss in the core of the dome-shaped Canigou massif. The first metamorphic stage is characterized by the crystallization of staurolite at $5.5 \mathrm{kbar}$ and $580^{\circ} \mathrm{C}$, following a prograde uppressure, up-temperature evolution through the peak pressure at $\sim 6.5 \mathrm{kbar}, 550{ }^{\circ} \mathrm{C}$, constrained by garnet zoning. It is associated with the S1 foliation, only preserved in the core of the Canigou massif. The second metamorphic stage, characterized by the crystallization of andalusite, implies a pressure decrease of about 2.5 kbar. It is coeval with the development of the main regional fabric S2 that transposes S1 and defines the dome shape of the massif. Resorption of garnet between the two metamorphic stages and its subsequent renewed growth is tentatively attributed to a two-stage $P-T$ path. This involves an exhumation dominated by erosion and/or slow extension followed by heating, probably associated with the delamination of the lithospheric mantle and the regional magmatic event. The c. 300 Ma monazite age is tentatively attributed to monazite recrystallization during the M2 LP-HT stage.

\section{ACKNOWLEDGEMENTS}

This work received the support of the Bureau de Recherches Géologiques et Minières (BRGM) through the "Référentiel Géologique de la France" programme (RGF). The newly acquired data compiled into the Geofield database will be available on the RGF website (www.rgf.brgm.fr). X. Le

This article is protected by copyright. All rights reserved. 
Coz is acknowledged for the efficient production of the numerous thin sections. We are grateful for the assistance in SEM observations and EDS analyses of the staff of the CMEBA facility (ScanMAT, University Rennes 1), which received a financial support from the Région Bretagne and the European Union (CPER-FEDER 2007-2014). The detailed reviews of J. Mezger and an anonymous reviewer, and the helpful editorial handling of M. Brown are gratefully acknowledged.

\section{CONFLICT OF INTEREST}

No conflict of interests to declare.

\section{REFERENCES}

Aguilar, C., Liesa, M., Castiñeiras, P., \& Navidad, M. (2014). Late Variscan metamorphic and magmatic evolution in the eastern Pyrenees revealed by $\mathrm{U}-\mathrm{Pb}$ age zircon dating. Journal of the Geological Society, 171(2), 181-192. https://doi.org/10.1144/jgs2012-086

Aguilar, C., Liesa, M., Štípská, P., Schulmann, K., Muñoz, J. A., \& Casas, J. M. (2015). P-T-t-d evolution of orogenic middle crust of the Roc de Frausa Massif (Eastern Pyrenees): a result of horizontal crustal flow and Carboniferous doming? Journal of Metamorphic Geology, 33(3), 273-294. https://doi.org/10.1111/jmg.12120

Auriol, L., \& Casteras, M. (1958). Les témoins de la couverture posthercynienne de la zone axiale à l'E et au SE du Canigou. Bulletin de La Société Géologique de France, S6-VIII(8), 871-880. https://doi.org/10.2113/gssgfbull.S6-VIII.8.871

Autran, A., Fonteilles, M., \& Guitard, G. (1966). Discordance du Paléozoïque inférieur métamorphique sur un socle gneissique antéhercynien dans le massif des Albères (Pyrénées orientales). Comptes Rendus de l'Académie Des Sciences, Paris, 263, 317-320.

This article is protected by copyright. All rights reserved. 
Autran, A., \& Guitard, G. (1970). Hysterogenic formation of kyanite in mesozonal micaschists with andalusite and sillimanite of Paleozoic series of the Cap de Creus, Eastern Pyrenees. Comptes Rendus de l'Académie Des Sciences, Paris, 270(22), 2616.

Azambre, B., \& Guitard, G. (2001). Disthène et staurotide reliques dans les métapelites du Canigou (Pyrénées orientales). Relations avec les épisodes hercyniens de basse et moyenne pressions. Comptes Rendus de l'Académie des Sciences, 333(10), 601-609. https://doi.org/10.1016/S1251-8050(01)01670-6

Ballouard, C., Boulvais, P., Poujol, M., Gapais, D., Yamato, P., Tartèse, R., \& Cuney, M. (2015). Tectonic record, magmatic history and hydrothermal alteration in the Hercynian Guérande leucogranite, Armorican Massif, France. Lithos, 220, 1-22. https://doi.org/10.1016/j.lithos.2015.01.027

Barbey, P., Cheilletz, A., \& Laumonier, B. (2001). The Canigou orthogneisses (Eastern Pyrenees, France, Spain): an Early Ordovician rapakivi granite laccolith and its contact aureole. Comptes Rendus de l'Académie Des Sciences - Series IIA - Earth and Planetary Science, 332(2), 129-136. https://doi.org/10.1016/S1251-8050(00)01506-8

Bixel, F., \& Lucas, C. L. (1983). Magmatisme, tectonique et sédimentation dans les fossés stéphanopermiens des Pyrénées occidentales. Revue de Géologie Dynamique et de Géographie Physique, 24(4), 329-342.

Carreras, J., \& Capella, I. (1994). Structures and Tectonics at Different Lithospheric Levels Tectonic levels in the Palaeozoic basement of the Pyrenees: a review and a new interpretation. Journal of Structural Geology, 16(11), 1509-1524. https://doi.org/10.1016/01918141(94)90029-9

Cherniak, D. J., Watson, E. B., Grove, M., \& Harrison, T. M. (2004). Pb diffusion in monazite: a combined RBS/SIMS. Geochimica et Cosmochimica Acta, 68(4), 829-840. https://doi.org/10.1016/j.gca.2003.07.012

This article is protected by copyright. All rights reserved. 
Cochelin, B., Chardon, D., Denèle, Y., Gumiaux, C., \& le Bayon, B. (2017). Vertical strain partitioning in hot Variscan crust: Syn-convergence escape of the Pyrenees in the IberianArmorican syntax. Bulletin de La Société Géologique de France, 188(6), 39. https://doi.org/10.1051/bsgf/2017206

Coggon, R., \& Holland, T. J. B. (2002). Mixing properties of phengitic micas and revised garnetphengite thermobarometers. Journal of Metamorphic Geology, 20(7), 683-696. https://doi.org/10.1046/j.1525-1314.2002.00395.x

Connolly, J. A. D., \& Cesare, B. (1993). C-O-H-S fluid composition and oxygen fugacity in graphitic metapelites. Journal of Metamorphic Geology, 11(3), 379-388. https://doi.org/10.1111/j.1525-1314.1993.tb00155.x

de Capitani, C., \& Brown, T. H. (1987). The computation of chemical equilibrium in complex systems containing non-ideal solutions. Geochimica et Cosmochimica Acta, 51(10), 26392652. https://doi.org/10.1016/0016-7037(87)90145-1

de Capitani, C., \& Petrakakis, K. (2010). The computation of equilibrium assemblage diagrams with Theriak/Domino software. American Mineralogist, 95(7), 1006-1016. https://doi.org/10.2138/am.2010.3354

Deloule, E., Alexandrov, P., Cheilletz, A., Laumonier, B., \& Barbey, P. (2002). In-situ U-Pb zircon ages for Early Ordovician magmatism in the eastern Pyrenees, France: the Canigou orthogneisses. International Journal of Earth Sciences, 91(3), 398-405. https://doi.org/10.1007/s00531-001-0232-0

Delvolvé, J.-J., Vachard, D., \& Souquet, P. (1998). Stratigraphic record of thrust propagation, Carboniferous foreland basin, Pyrenees, with emphasis on Pays-de-Sault (France/Spain). Geologische Rundschau, 87(3), 363-372. https://doi.org/10.1007/s005310050215

Denèle, Y., Laumonier, B., Paquette, J.-L., Olivier, P., Gleizes, G., \& Barbey, P. (2014). Timing of granite emplacement, crustal flow and gneiss dome formation in the Variscan segment of

This article is protected by copyright. All rights reserved. 
the Pyrenees. Geological Society, London, Special Publications, 405(1), 265-287.

https://doi.org/10.1144/SP405.5

Denèle, Y., Olivier, P., Gleizes, G., \& Barbey, P. (2009). Decoupling between the middle and upper crust during transpression-related lateral flow: Variscan evolution of the Aston gneiss dome (Pyrenees, France). Tectonophysics, 477(3), 244-261. https://doi.org/10.1016/j.tecto.2009.04.033

De Sitter, L.U. \& Zwart, H.J. 1960. Tectonic development in supra- and infrastructures of a mountain chain. In: Kale, A. \& Metzler, A. (eds) Structure of the Earth's crust and deformation of rocks, Proceedings 21 st International Geological Congress. Det Berlingske Bogtrykkeri, Copenhagen, 18, 248-256.

Dewey, J. F. (1988). Extensional collapse of orogens. Tectonics, 7(6), 1123-1139. https://doi.org/10.1029/TC007i006p01123

Didier, A., Bosse, V., Boulvais, P., Bouloton, J., Paquette, J.-L., Montel, J.-M., \& Devidal, J.-L. (2013). Disturbance versus preservation of $\mathrm{U}-\mathrm{Th}-\mathrm{Pb}$ ages in monazite during fluid-rock interaction: textural, chemical and isotopic in situ study in microgranites (Velay Dome, France). Contributions to Mineralogy and Petrology, 165(6), 1051-1072. https://doi.org/10.1007/s00410-012-0847-0

Diener, J. F. A., \& Powell, R. (2012). Revised activity-composition models for clinopyroxene and amphibole. Journal of Metamorphic Geology, 30(2), 131-142. https://doi.org/10.1111/j.1525-1314.2011.00959.x

Driouch, Y., Dahmani, A., Debat, P., Pouget, P., Seyler, M., \& Soula, J. C. (1989). Les formations ultrabasiques et basiques au sein des séries mésocrustales des Pyrénées hercyniennes. Comptes Rendus de l'Académie Des Sciences., 308(14), 1249-1255.

This article is protected by copyright. All rights reserved. 
Druguet, E., 2001. Development of high thermal gradients by coeval transpression and magmatism during the Variscan orogeny: insights from the Cap de Creus (Eastern Pyrenees). Tectonophysics, 332, 275-293.

Druguet, E., Castro, A., Chichorro, M., Pereira, M. F., \& Fernández, C. (2014). Zircon geochronology of intrusive rocks from Cap de Creus, Eastern Pyrenees. Geological Magazine, 151(6), 1095-1114. https://doi.org/10.1017/S0016756814000041

Engel, W., \& Raymond, D. (1983). Phénomènes de resédimentation dans le Carbonifère a faciés Culm du Haut Pays de Sault (E de la zone primaire axiale pyrénéenne, France). Signification géodynamique dans la branche sud de l'orogène varisque. Bulletin de La Société Géologique de France, S7-XXV(6), 921-926. https://doi.org/10.2113/gssgfbull.S7XXV.6.921

England, P. C., \& Thompson, A. B. (1984). Pressure-Temperature-Time Paths of Regional Metamorphism I. Heat Transfer during the Evolution of Regions of Thickened Continental Crust. Journal of Petrology, 25(4), 894-928. https://doi.org/10.1093/petrology/25.4.894

Esteban, J. J., Aranguren, A., Cuevas, J., Hilario, A., Tubía, J. M., Larionov, A., \& Sergeev, S. (2015). Is there a time lag between the metamorphism and emplacement of plutons in the Axial Zone of the Pyrenees? Geological Magazine, 152(5), 935-941. https://doi.org/10.1017/S001675681500014X

Feenstra, A. (1996). An EMP and TEM-AEM Study of Margarite, Muscovite and Paragonite in Polymetamorphic Metabauxites of Naxos Cyclades, Greece) and the Implications of Finescale Mica Interlayering and Multiple Mica Generations. Journal of Petrology, 37(2), 201233. https://doi.org/10.1093/petrology/37.2.201

Fontboté, J. M., \& Guitard, G. (1958). Aperçus sur la tectonique cassante de la zone axiale des Pyrenees orientales entre les bassins de Cerdagne et de l'Ampurdan-Roussillon. Bulletin de

This article is protected by copyright. All rights reserved. 
La Société Géologique de France, S6-VIII(8), 884-890.

https://doi.org/10.2113/gssgfbull.S6-VIII.8.884

Fonteilles, M., \& Guitard, G. (1971). Disthène relique et disthène hystérogène dans les terrains métamorphiques hercyniens des Pyrénées orientales franco-espagnoles. Comptes Rendus de l'Académie Des Sciences, Paris, 272, 361-363.

Gardien, V., Lardeaux, J.-M., Ledru, P., Allemand, P., \& Guillot, S. (1997). Metamorphism during late orogenic extension; insights from the French Variscan belt. Bulletin de La Société Géologique de France, 168(3), 271-286.

Gasquet, D., Bertrand, J. M., Paquette, J. L., Lehmann, J., Ratzov, G., Guedes, R. D. A., ... Nomade, S. (2010). Miocene to Messinian deformation and hydrothermal activity in a pre-Alpine basement massif of the French western Alps: new U-Th-Pb and argon ages from the Lauzière massif. Bulletin de La Société Géologique de France, 181(3), 227-241. https://doi.org/10.2113/gssgfbull.181.3.227

Gibson, R. L. (1991). Hercynian low-pressure-high-temperature regional metamorphism and subhorizontal foliation development in the Canigou massif, Pyrenees, France-Evidence for crustal extension. Geology, 19(4), 380-383. https://doi.org/10.1130/00917613(1991)019<0380:HLPHTR>2.3.CO;2

Gibson, R. L. (1992). Sequential, syndeformational porphyroblast growth during Hercynian lowpressure/high-temperature metamorphism in the Canigou massif, Pyrenees. Journal of Metamorphic Geology, 10(5), 637-650. https://doi.org/10.1111/j.1525-1314.1992.tb00112.x

Gibson, R. L., \& Bickle, M. J. (1994). Thermobarometric constraints on the conditions of metamorphism in the Canigou massif, Pyrenees: implications for Hercynian geothermal gradients. Journal of the Geological Society, 151(6), 987-997. https://doi.org/10.1144/gsjgs.151.6.0987

This article is protected by copyright. All rights reserved. 
Gleizes, G., Leblanc, D., \& Bouchez, J. L. (1998). The main phase of the Hercynian orogeny in the Pyrenees is a dextral transpression. Geological Society, London, Special Publications, 135(1), 267-273. https://doi.org/10.1144/GSL.SP.1998.135.01.17

Guitard, G. (1970). Le métamorphisme hercynien mésozonal et les gneiss oeillés du massif du Canigou:(Pyrénées-Orientales). Mémoires du BRGM, 63, 353 pp.

Guitard, G., Laumonier, B., Autran, A., Bandet, Y., \& Berger, G. M. (1998). Notice explicative, Carte géol. France (1/50 000), feuille Prades (1095). Orléans : BRGM, 198 p. Carte géologique par G. Guitard et al. (1992).

Gutiérrez-Alonso, G., Murphy, J. B., Fernández-Suárez, J., Weil, A. B., Franco, M. P., \& Gonzalo, J. C. (2011). Lithospheric delamination in the core of Pangea: Sm-Nd insights from the Iberian mantle. Geology, 39(2), 155-158. https://doi.org/10.1130/G31468.1

Henk, A., Blanckenburg, F. von, Finger, F., Schaltegger, U., \& Zulauf, G. (2000). Syn-convergent high-temperature metamorphism and magmatism in the Variscides: a discussion of potential heat sources. Geological Society, London, Special Publications, 179(1), 387-399. https://doi.org/10.1144/GSL.SP.2000.179.01.23

Höck, V. (1974). Coexisting phengite, paragonite and margarite in metasediments of the mittlere Hohe Tauern, Austria. Contributions to Mineralogy and Petrology, 43(4), 261-273. https://doi.org/10.1007/BF00373483

Holland, T., \& Blundy, J. (1994). Non-ideal interactions in calcic amphiboles and their bearing on amphibole-plagioclase thermometry. Contributions to Mineralogy and Petrology, 116(4), 433-447. https://doi.org/10.1007/BF00310910

Holland, T., \& Powell, R. (1998). An internally consistent thermodynamic data set for phases of petrological interest. Journal of Metamorphic Geology, 16(3), 309-343. https://doi.org/10.1111/j.1525-1314.1998.00140.x

This article is protected by copyright. All rights reserved. 
Holland, T., \& Powell, R. (2003). Activity-composition relations for phases in petrological calculations: an asymmetric multicomponent formulation. Contributions to Mineralogy and Petrology, 145(4), 492-501. https://doi.org/10.1007/s00410-003-0464-z

Holland, T., Baker, J., \& Powell, R. (1998). Mixing properties and activity-composition relationships of chlorites in the system $\mathrm{MgO}-\mathrm{FeO}-\mathrm{Al} 2 \mathrm{O} 3-\mathrm{SiO} 2-\mathrm{H} 2 \mathrm{O}$. European Journal of Mineralogy, 395-406. https://doi.org/10.1127/ejm/10/3/0395

Houseman, G. A., McKenzie, D. P., \& Molnar, P. (1981). Convective instability of a thickened boundary layer and its relevance for the thermal evolution of continental convergent belts. Journal of Geophysical Research: Solid Earth, 86(B7), 6115-6132. https://doi.org/10.1029/JB086iB07p06115

Kilzi, M. A., Grégoire, M., Bosse, V., Benoît, M., Driouch, Y., de Saint Blanquat, M. \& Debat, P., 2016. Geochemistry and zircon U-Pb geochronology of the ultramafic and mafic rocks emplaced within the anatectic series of the Variscan Pyrenees: The example of the Gavarnie-Heas dome (France). Comptes Rendus Geoscience, 348, 107-115.

Kohn, M. J. (2016). Metamorphic chronology—a tool for all ages: Past achievements and future prospects. American Mineralogist, 101(1), 25-42. https://doi.org/10.2138/am-2016-5146

Kohn, M. J., Wieland, M. S., Parkinson, C. D., \& Upreti, B. N. (2005). Five generations of monazite in Langtang gneisses: implications for chronology of the Himalayan metamorphic core. Journal of Metamorphic Geology, 23(5), 399-406. https://doi.org/10.1111/j.15251314.2005.00584.x

Korhonen, F. J., Brown, M., Clark, C. \& Bhattacharya, S., 2013. Osumilite-melt interactions in ultrahigh temperature granulites: phase equilibria modelling and implications for the $\mathrm{P}-\mathrm{T}-\mathrm{t}$ evolution of the Eastern Ghats Province, India. Journal of Metamorphic Geology, 31, 881907. https://doi.org/10.1111/jmg.12049

This article is protected by copyright. All rights reserved. 
Lago, M., Arranz, E., Pocoví, A., Galé, C., \& Gil-Imaz, A. (2004). Permian magmatism and basin dynamics in the southern Pyrenees: a record of the transition from late Variscan transtension to early Alpine extension. Geological Society, London, Special Publications, 223(1), 439464. https://doi.org/10.1144/GSL.SP.2004.223.01.19

Lardeaux, J. M. (2014). Deciphering orogeny: a metamorphic perspective Examples from European Alpine and Variscan belts. Bulletin de La Société Géologique de France, 185(5), 281-310. https://doi.org/10.2113/gssgfbull.185.5.281

Laumonier, B., Le Bayon, B., \& Calvet, M. (2015). Carte géologique France (1/50 000), feuille Pratsde-Mollo-La-Preste (1099). Orléans : BRGM. Notice explicative par Laumonier, B., Calvet, M., Le Bayon, B., Barbey, P., Lenoble, J.-L., 2015, 189p. Orléans.

Laumonier, B., Marignac, C., \& Kister, P. (2010). Polymétamorphisme et évolution crustale dans les Pyrénées orientales pendant l'orogenèse varisque au Carbonifère supérieur. Bulletin de la Société géologique de France, 181(5), 411-428.

Le Bayon, B., Pitra, P., Ballevre, M., \& Bohn, M. (2006). Reconstructing P-T paths during continental collision using multi-stage garnet (Gran Paradiso nappe, Western Alps). Journal of Metamorphic Geology, 24(6), 477-496. https://doi.org/10.1111/j.15251314.2006.00649.x

Lexa, O., Schulmann, K., Janoušek, V., Štípská, P., Guy, A., \& Racek, M. (2011). Heat sources and trigger mechanisms of exhumation of HP granulites in Variscan orogenic root. Journal of Metamorphic Geology, 29(1), 79-102. https://doi.org/10.1111/j.1525-1314.2010.00906.x

López-Carmona, A., Pitra, P., \& Abati, J. (2013). Blueschist-facies metapelites from the Malpica-Tui Unit (NW Iberian Massif): phase equilibria modelling and $\mathrm{H} 2 \mathrm{O}$ and $\mathrm{Fe} 2 \mathrm{O} 3$ influence in high-pressure assemblages. Journal of Metamorphic Geology, 31(3), 263-280. https://doi.org/10.1111/jmg.12018

This article is protected by copyright. All rights reserved. 
Lopez-Sanchez, M. A., García-Sansegundo, J., \& Martínez, F. J. (2018). The significance of early Permian and early Carboniferous U-Pb zircon ages in the Bossòst and Lys-Caillaouas granitoids (Pyrenean Axial Zone). Geological Journal, O(0). https://doi.org/10.1002/gj.3283

Ludwig, K. R. (2012). Isoplot/Ex, v. 3.75. Berkeley Geochronology Center Special Publication, 5.

Martín-Closas, C., Trias, S., \& Casas Tuset, J. M. (2018). New palaeobotanical data from Carboniferous Culm deposits constrain the age of the Variscan deformation in the eastern Pyrenees. Geologica acta, 16(2), 0107-0123. https://doi.org/10.1344/GeologicaActa2018.16.2.1

Martìnez, F. J., Reche, J., \& Arboleya, M. L. (2001). P-T modelling of the andalusite-kyaniteandalusite sequence and related assemblages in high-Al graphitic pelites. Prograde and retrograde paths in a late kyanite belt in the Variscan Iberia. Journal of Metamorphic Geology, 19(6), 661-677. https://doi.org/10.1046/j.0263-4929.2001.00335.x

Maurel, O., Monié, P., Pik, R., Arnaud, N., Brunel, M., \& Jolivet, M. (2008). The Meso-Cenozoic thermo-tectonic evolution of the Eastern Pyrenees: an 40Ar/39Ar fission track and (UTh)/He thermochronological study of the Canigou and Mont-Louis massifs. International Journal of Earth Sciences, 97(3), 565-584.

Ménard, G., \& Molnar, P. (1988). Collapse of a Hercynian Tibetan Plateau into a late Palaeozoic European Basin and Range province. Nature, 334(6179), 235. https://doi.org/10.1038/334235a0

Mezger, J. E. (2009). Transpressional tectonic setting during the main Variscan deformation: evidence from four structural levels in the Bossòst and Aston-Hospitalet mantled gneiss domes, central Axial Zone, Pyrenees. Bulletin de La Société Géologique de France, 180(3), 199207. https://doi.org/10.2113/gssgfbull.180.3.199

This article is protected by copyright. All rights reserved. 
Mezger, J. E., \& Gerdes, A. (2016). Early Variscan (Visean) granites in the core of central Pyrenean gneiss domes: implications from laser ablation $\mathrm{U}-\mathrm{Pb}$ and $\mathrm{Th}-\mathrm{Pb}$ studies. Gondwana Research, 29(1), 181-198. https://doi.org/10.1016/j.gr.2014.11.010

Mezger, J. E., \& Passchier, C. W. (2003). Polymetamorphism and ductile deformation of staurolitecordierite schist of the Bossòst dome: indication for Variscan extension in the Axial Zone of the central Pyrenees. Geological Magazine, 140(5), 595-612. https://doi.org/10.1017/S0016756803008112

Mezger, J. E., Passchier, C. W., \& Régnier, J. L. (2004). Metastable staurolite-cordierite assemblage of the Bossòst dome: Late Variscan decompression and polyphase metamorphism in the Axial Zone of the central Pyrenees. Comptes Rendus Geoscience, 336(9), 827-837. https://doi.org/10.1016/j.crte.2003.12.024

Mezger, J. E., \& Régnier, J.-L. (2016). Stable staurolite-cordierite assemblages in K-poor metapelitic schists in Aston and Hospitalet gneiss domes of the central Pyrenees (France, Andorra). Journal of Metamorphic Geology, 34(2), 167-190. https://doi.org/10.1111/jmg.12177

Monié, P., Soliva, J., Brunel, M., \& Maluski, H. (1994). Les cisaillements mylonitiques du granite de Millas (Pyrénées, France). Age Crétacé 40 Ar/ 39 Ar et interprétation tectonique. Bulletin de La Société Géologique de France, 165(6), 559-571.

Padel, M., Álvaro, J. J., Casas, J. M., Clausen, S., Poujol, M., \& Sánchez-García, T. (2017). Cadomian volcanosedimentary complexes across the Ediacaran-Cambrian transition of the Eastern Pyrenees, southwestern Europe. International Journal of Earth Sciences, 1-23. https://doi.org/10.1007/s00531-017-1559-5

Paquette, J. L., Ballèvre, M., Peucat, J. J., \& Cornen, G. (2017). From opening to subduction of an oceanic domain constrained by LA-ICP-MS U-Pb zircon dating (Variscan belt, Southern Armorican Massif, France). Lithos, 294-295(Supplement C), 418-437. https://doi.org/10.1016/j.lithos.2017.10.005

This article is protected by copyright. All rights reserved. 
Paquette, J. L., \& Tiepolo, M. (2007). High resolution (5 $\mu \mathrm{m}) \mathrm{U}-\mathrm{Th}-\mathrm{Pb}$ isotope dating of monazite with excimer laser ablation (ELA)-ICPMS. Chemical Geology, 240(3), 222-237. https://doi.org/10.1016/j.chemgeo.2007.02.014

Parrish, R. R. (1990). U-Pb dating of monazite and its application to geological problems. Canadian Journal of Earth Sciences, 27(11), 1431-1450. https://doi.org/10.1139/e90-152

Pin, C. (1990). Variscan oceans: ages, origins and geodynamic implications inferred from geochemical and radiometric data. Tectonophysics, 177(1), 215-227.

Pitra, P., \& Guiraud, M. (1996). Probable anticlockwise P,-T evolution in extending crust: Hlinsko region, Bohemian Massif. Journal of Metamorphic Geology, 14(1), 49-60. https://doi.org/10.1111/j.1525-1314.1996.t01-1-00049.x

Platt, J. P. (1993). Exhumation of high-pressure rocks: a review of concepts and processes. Terra Nova, 5(2), 119-133. https://doi.org/10.1111/j.1365-3121.1993.tb00237.x

Powell, R., \& Holland, T. J. B. (1988). An internally consistent dataset with uncertainties and correlations: 3. Applications to geobarometry, worked examples and a computer program. Journal of Metamorphic Geology, 6(2), 173-204. https://doi.org/10.1111/j.15251314.1988.tb00415.x

Powell, R. \& Holland, T. J. B., (2002). Course Notes for "THERMOCALC Workshop 2002: Calculating Metamorphic Phase Equilibria"(Barcelona). CD-ROM.

Rey, P. F., Teyssier, C., \& Whitney, D. L. (2009). Extension rates, crustal melting, and core complex dynamics. Geology, 37(5), 391-394. https://doi.org/10.1130/G25460A.1

Shaw, D. M. (1956). Geochemistry of pelitic rocks. Part III: Major element and general geochemistry. GSA Bulletin, 67(7), 919-934. https://doi.org/10.1130/00167606(1956)67[919:GOPRPI]2.0.CO;2

This article is protected by copyright. All rights reserved. 
Smith, H. A., \& Barreiro, B. (1990). Monazite U-Pb dating of staurolite grade metamorphism in pelitic schists. Contributions to Mineralogy and Petrology, 105(5), 602-615. https://doi.org/10.1007/BF00302498

Soliva, J., Salel, J. F., \& Brunel, M. (1989). Shear deformation and emplacement of the gneissic Canigou thrust nappe (Eastern Pyrenees). Geologie En Mijnbouw, 68(3), 357-366.

Sonder, L. J., England, P. C., Wernicke, B. P., \& Christiansen, R. L. (1987). A physical model for Cenozoic extension of western North America. Geological Society, London, Special Publications, 28(1), 187-201. https://doi.org/10.1144/GSL.SP.1987.028.01.14

Soula, J. C. (1982). Characteristics and mode of emplacement of gneiss domes and plutonic domes in central-eastern Pyrenees. Journal of Structural Geology, 4(3), 313-342. https://doi.org/10.1016/0191-8141(82)90017-7

Soula, J. C., Debat, P., Deramond, J., \& Pouget, P. (1986). A dynamic model of the structural evolution of the Hercynian Pyrenees. Tectonophysics, 129(1), 29-51. https://doi.org/10.1016/0040-1951(86)90244-1

Spear, F. S. (2010). Monazite-allanite phase relations in metapelites. Chemical Geology, 279(1), 5562. https://doi.org/10.1016/j.chemgeo.2010.10.004

Spear, F. S., \& Pyle, J. M. (2002). Apatite, Monazite, and Xenotime in Metamorphic Rocks. Reviews in Mineralogy and Geochemistry, 48(1), 293-335. https://doi.org/10.2138/rmg.2002.48.7

Speksnijder, A. (1985). Anatomy of a strike-slip fault controlled sedimentary basin, Permian of the Southern Pyrenees, Spain. Sedimentary Geology, 44(3), 179-223. https://doi.org/10.1016/0037-0738(85)90014-4

Štípská, P., Hacker, B. R., Racek, M., Holder, R., Kylander-Clark, A. R. C., Schulmann, K., \& Hasalová, P. (2015). Monazite Dating of Prograde and Retrograde P-T-d paths in the

This article is protected by copyright. All rights reserved. 
Barrovian terrane of the Thaya window, Bohemian Massif. Journal of Petrology, 56(5), 1007-1035. https://doi.org/10.1093/petrology/egv026

Tartèse, R., Ruffet, G., Poujol, M., Boulvais, P., \& Ireland, T. R. (2011). Simultaneous resetting of the muscovite K-Ar and monazite U-Pb geochronometers: a story of fluids. Terra Nova, 23(6), 390-398. https://doi.org/10.1111/j.1365-3121.2011.01024.x

Thompson, A. B., \& England., P. C. (1984). Pressure-temperature-time paths of regional metamorphism II. Their inference and interpretation using mineral assemblages in metamorphic rocks. Journal of Petrology, 25(4), 929-955.

Van Achterbergh, E., Ryan, C. G., \& Griffin, W. L. (2001). GLITTER on-line interactive data reduction for the LA-ICPMS microprobe. Macquarie Research Ltd., Sydney.

Vilà, M., Pin, C., Liesa, M., \& Enrique, P. (2007). LPHT metamorphism in a late orogenic transpressional setting, Albera Massif, NE Iberia: implications for the geodynamic evolution of the Variscan Pyrenees. Journal of Metamorphic Geology, 25(3), 321-347. https://doi.org/10.1111/j.1525-1314.2007.00698.x

Vissers, R. L. M. (1992). Variscan extension in the Pyrenees. Tectonics, 11(6), 1369-1384. https://doi.org/10.1029/92TC00823

Vissers, R. L. M., Hinsbergen, D. J. J. van, Ganerød, M., \& Wilkinson, C. M. (2018). Reply to discussion on 'Middle Jurassic shear zones at Cap de Creus (eastern Pyrenees, Spain): a record of pre-drift extension of the Piemonte-Ligurian Ocean?' Journal of the Geological Society, London, 174, 289-300. Journal of the Geological Society, 175(1), 189-191. https://doi.org/10.1144/jgs2017-115

Vissers, R. L. M., Hinsbergen, D. J. J. van, Wilkinson, C. M., \& Ganerød, M. (2017). Middle Jurassic shear zones at Cap de Creus (eastern Pyrenees, Spain): a record of pre-drift extension of the Piemonte-Ligurian Ocean? Journal of the Geological Society, 174(2), 289-300. https://doi.org/10.1144/jgs2016-014

This article is protected by copyright. All rights reserved. 
White, R. W., Pomroy, N. E., \& Powell, R. (2005). An in situ metatexite-diatexite transition in upper amphibolite facies rocks from Broken Hill, Australia. Journal of Metamorphic Geology, 23(7), 579-602. https://doi.org/10.1111/j.1525-1314.2005.00597.x

White, R. W., Powell, R., Holland, T. J. B., \& Worley, B. A. (2000). The effect of TiO2 and Fe2O3 on metapelitic assemblages at greenschist and amphibolite facies conditions: mineral equilibria calculations in the system $\mathrm{K} 2 \mathrm{O}-\mathrm{FeO}-\mathrm{MgO}-\mathrm{A} 2 \mathrm{O} 3-\mathrm{SiO} 2-\mathrm{H} 2 \mathrm{O}-\mathrm{TiO} 2-\mathrm{Fe} 2 \mathrm{O} 3$. Journal of Metamorphic Geology, 18(5), 497-511. https://doi.org/10.1046/j.15251314.2000.00269.x

Wickham, S. M., \& Oxburgh, E. R. (1986). A rifted tectonic setting for hercynian high-thermal gradient metamorphism in the pyrenees. Tectonophysics, 129(1), 53-69. https://doi.org/10.1016/0040-1951(86)90245-3

Williams, M. L., Jercinovic, M. J., Harlov, D. E., Budzyń, B., \& Hetherington, C. J. (2011). Resetting monazite ages during fluid-related alteration. Chemical Geology, 283(3), 218-225. https://doi.org/10.1016/j.chemgeo.2011.01.019

Wing, B. A., Ferry, J. M., \& Harrison, T. M. (2003). Prograde destruction and formation of monazite and allanite during contact and regional metamorphism of pelites: petrology and geochronology. Contributions to Mineralogy and Petrology, 145(2), 228-250. https://doi.org/10.1007/s00410-003-0446-1

Zwart, H. J. (1979). The geology of the central Pyrenees. Leidse Geologische Mededelingen, 50, 174.

This article is protected by copyright. All rights reserved. 


\section{SUPPORTING INFORMATION}

Additional Supporting Information may be found online in the supporting information tab for this article.

Figure S1. Sketch map of the major gneissic domes and plutons of the Zone-Axial of the Pyrenees. The bold legend refers to localities cited in the text.

Figure S2. $P-T$ pseudosections for the sample LH16 calculated using THERMOCALC (a) and Theriak/Domino (b). $\mathrm{H}_{2} \mathrm{O}$ is considered in excess, the other phases marked in the header $(\mathrm{g}, \mathrm{mu}, \mathrm{q}$, ilm) are present in all fields, unless otherwise marked. Abbreviations along the lines indicate the mineral that is lost/gained. Grey shading in (b) highlights differences between the two diagrams. Other colours represent stability fields for key minerals: epidote (blue), staurolite (yellow), andalusite (pink).

Figure S3. $P-X\left(\mathrm{Fe}^{3+}\right)$ pseudosection showing the influence of the proportion of ferric iron on the stability of minerals for $\mathrm{Fe}^{3+}$ varying between $0 \%$ and $5 \%$ out of total iron. The range in (b) corresponds to the grey area in (a). Solid black line shows the ferric iron proportion used for further calculations (1\%).

Figure S4. Pseudosection for the garnet-grunerite-bearing sample LH9.

Table S1. Review of the available pseudosection-based $P-T$ conditions in the Axial Zone of the Pyrenees.

Table S2. Operating conditions for the LA-ICP-MS equipment.

This article is protected by copyright. All rights reserved. 
Table 1: Table of representative microprobe analyses.

Lithology Micaschist

Sample LH1B

LH16

\begin{tabular}{|c|c|c|c|c|c|c|c|c|c|c|c|c|c|c|c|c|c|c|}
\hline Analysis\# & $\begin{array}{l}\text { p011 } \\
111\end{array}$ & p020 & 401 & 113 & 206 & 311 & 112 & 307 & p106 & MEB1 & p001 & 107 & 306 & 013 & 022 & 021 & 425 & 035 \\
\hline Mineral & $\begin{array}{l}\mathrm{g} \\
\text { ilm }\end{array}$ & $\mathrm{g}$ & $\mathrm{mu}$ & bi & bi & chl & $\mathrm{pl}$ & ilm & $\mathrm{g}$ & $\mathrm{g}$ & $\mathrm{g}$ & st & $\mathrm{mu}$ & bi & bi & chl & $\mathrm{pl}$ & ep \\
\hline Position & $\mathrm{g} 1 \mathrm{~g} 2$ & matrix & in $g$ & in and & matrix & in and & matrix & core & rim & \multicolumn{2}{|c|}{ outer rim } & in and & matrix & matrix & in and & matrix & in $g$ & in st. \\
\hline $\mathrm{SiO}_{2}$ & $\begin{array}{l}36.18 \\
0.04\end{array}$ & 36.60 & 46.01 & 33.77 & 34.24 & 28.03 & 60.68 & 0.06 & 36.65 & 36.63 & 35.90 & 27.25 & 45.22 & 33.36 & 33.81 & 23.36 & 59.78 & 38.42 \\
\hline $\mathrm{TiO}_{2}$ & $\begin{array}{l}0.05 \\
52.91\end{array}$ & 0.04 & 0.51 & 2.89 & 1.56 & 0.31 & 0.05 & 53.33 & 0.14 & 0.00 & 0.05 & 0.75 & 0.51 & 1.93 & 2.25 & 0.11 & 0.00 & 0.14 \\
\hline $\mathrm{Al}_{2} \mathrm{O}_{3}$ & $\begin{array}{l}20.94 \\
0.02\end{array}$ & 21.25 & 35.99 & 19.18 & 20.88 & 20.44 & 24.55 & 0.03 & 20.99 & 20.98 & 21.11 & 56.42 & 37.22 & 19.63 & 21.59 & 23.68 & 25.53 & 29.73 \\
\hline $\mathrm{MgO}$ & $\begin{array}{l}1.74 \\
0.05\end{array}$ & 1.24 & 0.70 & 7.61 & 7.56 & 10.64 & 0.00 & 0.03 & 1.17 & 1.37 & 2.09 & 0.87 & 0.50 & 8.25 & 7.61 & 12.03 & 0.03 & 0.03 \\
\hline $\mathrm{FeO}$ & $\begin{array}{l}30.49 \\
44.42\end{array}$ & 29.26 & 1.31 & 21.99 & 20.49 & 26.94 & 0.35 & 40.65 & 27.08 & 30.14 & 30.86 & 12.67 & 0.82 & 21.22 & 19.67 & 27.65 & 0.06 & 5.73 \\
\hline $\mathrm{MnO}$ & $\begin{array}{l}9.05 \\
2.25\end{array}$ & 10.55 & 0.00 & 0.42 & 0.18 & 0.22 & 0.03 & 4.28 & 6.14 & 5.77 & 7.09 & 0.49 & 0.00 & 0.09 & 0.19 & 0.32 & 0.00 & 0.29 \\
\hline $\mathrm{ZnO}$ & $\begin{array}{l}0.00 \\
0.00\end{array}$ & 0.00 & 0.00 & 0.00 & 0.00 & 0.10 & 0.00 & 0.00 & 0.00 & 0.00 & 0.03 & 0.34 & 0.00 & 0.00 & 0.00 & 0.00 & 0.00 & 0.00 \\
\hline $\mathrm{CaO}$ & $\begin{array}{l}2.08 \\
0.01\end{array}$ & 1.46 & 0.02 & 0.07 & 0.03 & 0.15 & 5.58 & 0.04 & 7.30 & 5.12 & 2.42 & 0.01 & 0.03 & 0.00 & 0.00 & 0.05 & 6.74 & 23.12 \\
\hline $\mathrm{P}_{2} \mathrm{O}_{5}$ & $\begin{array}{l}0.00 \\
0.00\end{array}$ & 0.00 & 0.03 & 0.05 & 0.00 & 0.00 & 0.11 & 0.00 & 0.00 & 0.00 & 0.00 & 0.00 & 0.00 & 0.00 & 0.00 & 0.01 & 0.04 & 0.06 \\
\hline $\mathrm{Na}_{2} \mathrm{O}$ & $\begin{array}{l}0.00 \\
0.00\end{array}$ & 0.00 & 0.78 & 0.16 & 0.20 & 0.02 & 8.31 & 0.00 & 0.00 & 0.00 & 0.00 & 0.00 & 0.95 & 0.10 & 0.14 & 0.00 & 7.53 & 0.00 \\
\hline $\mathrm{K}_{2} \mathrm{O}$ & $\begin{array}{l}0.00 \\
0.00\end{array}$ & 0.04 & 10.11 & 9.01 & 9.13 & 0.86 & 0.05 & 0.02 & 0.00 & 0.00 & 0.16 & 0.01 & 10.19 & 9.56 & 8.98 & 0.01 & 0.05 & 0.06 \\
\hline Sum & $\begin{array}{l}100.54 \\
99.70\end{array}$ & 100.43 & 95.45 & 95.15 & 94.27 & 87.71 & 99.69 & 98.43 & 99.46 & 100.00 & 99.68 & 98.81 & 95.43 & 94.15 & 94.23 & 87.22 & 99.75 & 97.57 \\
\hline $\mathrm{Si}$ & $\begin{array}{l}2.93 \\
0.00\end{array}$ & 2.97 & 3.05 & 2.62 & 2.65 & 2.97 & 2.71 & 0.00 & 2.96 & 2.94 & 2.91 & 7.79 & 3.00 & 2.61 & 2.60 & 2.51 & 2.67 & 2.96 \\
\hline $\mathrm{Ti}$ & $\begin{array}{l}0.00 \\
1.00\end{array}$ & 0.00 & 0.03 & 0.17 & 0.09 & 0.03 & 0.00 & 1.02 & 0.01 & 0.00 & 0.00 & 0.16 & 0.03 & 0.11 & 0.13 & 0.01 & 0.00 & 0.01 \\
\hline
\end{tabular}

This article is protected by copyright. All rights reserved. 


\begin{tabular}{|c|c|c|c|c|c|c|c|c|c|c|c|c|c|c|c|c|c|}
\hline $\mathrm{Al}$ & $\begin{array}{l}2.00 \\
0.00\end{array}$ & 2.03 & 2.81 & 1.75 & 1.90 & 2.55 & 1.29 & 0.00 & 2.00 & 1.98 & 2.02 & 19.01 & 2.91 & 1.81 & 1.96 & 3.00 & 1.34 \\
\hline $\mathrm{Fe}^{3+}$ & $\begin{array}{l}0.14 \\
0.00\end{array}$ & 0.02 & 0.00 & 0.00 & 0.00 & 0.00 & 0.00 & 0.00 & 0.05 & 0.00 & 0.16 & 0.00 & 0.00 & 0.00 & 0.00 & 0.00 & 0.00 \\
\hline $\mathrm{Mg}$ & $\begin{array}{l}0.21 \\
0.00\end{array}$ & 0.15 & 0.07 & 0.88 & 0.87 & 1.68 & 0.00 & 0.00 & 0.14 & 0.19 & 0.25 & 0.37 & 0.05 & 0.96 & 0.87 & 1.93 & 0.00 \\
\hline $\mathrm{Fe}^{2+}$ & $\begin{array}{l}1.92 \\
0.94\end{array}$ & 1.96 & 0.07 & 1.43 & 1.32 & 2.39 & 0.01 & 0.86 & 1.78 & 2.09 & 1.93 & 3.03 & 0.05 & 1.39 & 1.27 & 2.49 & 0.00 \\
\hline $\mathrm{Mn}$ & $\begin{array}{l}0.62 \\
0.05\end{array}$ & 0.73 & 0.00 & 0.03 & 0.01 & 0.02 & 0.00 & 0.09 & 0.42 & 0.26 & 0.49 & 0.12 & 0.00 & 0.01 & 0.01 & 0.03 & 0.00 \\
\hline $\mathrm{Zn}$ & $\begin{array}{l}0.00 \\
0.00\end{array}$ & 0.00 & 0.00 & 0.00 & 0.00 & 0.01 & 0.00 & 0.00 & 0.00 & 0.00 & 0.00 & 0.07 & 0.00 & 0.00 & 0.00 & 0.00 & 0.00 \\
\hline $\mathrm{Ca}$ & $\begin{array}{l}0.18 \\
0.00\end{array}$ & 0.13 & 0.00 & 0.01 & 0.00 & 0.02 & 0.27 & 0.00 & 0.63 & 0.55 & 0.21 & 0.00 & 0.00 & 0.00 & 0.00 & 0.01 & 0.32 \\
\hline $\mathrm{P}$ & $\begin{array}{l}0.00 \\
0.00\end{array}$ & 0.00 & 0.00 & 0.00 & 0.00 & 0.00 & 0.00 & 0.00 & 0.00 & 0.00 & 0.00 & 0.00 & 0.00 & 0.00 & 0.00 & 0.00 & 0.00 \\
\hline $\mathrm{Na}$ & $\begin{array}{l}0.00 \\
0.00\end{array}$ & 0.00 & 0.10 & 0.02 & 0.03 & 0.01 & 0.72 & 0.00 & 0.00 & 0.00 & 0.00 & 0.00 & 0.12 & 0.02 & 0.02 & 0.00 & 0.65 \\
\hline $\mathrm{K}$ & $\begin{array}{l}0.00 \\
0.00\end{array}$ & 0.00 & 0.86 & 0.89 & 0.90 & 0.12 & 0.00 & 0.00 & 0.00 & 0.00 & 0.02 & 0.00 & 0.86 & 0.95 & 0.88 & 0.00 & 0.00 \\
\hline $\mathrm{OH}$ & $\begin{array}{l}0.00 \\
0.00\end{array}$ & 0.00 & 2.00 & 2.00 & 2.00 & 8.00 & 0.00 & 0.00 & 0.00 & 0.00 & 0.00 & 0.00 & 2.00 & 2.00 & 2.00 & 8.00 & 0.00 \\
\hline Sum & $\begin{array}{l}8.00 \\
1.99\end{array}$ & 8.00 & 8.99 & 9.79 & 9.78 & 17.79 & 5.00 & 1.98 & 8.00 & 8.00 & 8.00 & 30.55 & 9.01 & 9.86 & 9.74 & 17.98 & 4.99 \\
\hline$X_{\mathrm{Fe}} / X_{\mathrm{Na}}$ & 0.90 & 0.93 & 0.10 & 0.62 & 0.60 & 0.59 & & & 0.93 & 0.92 & 0.88 & 0.89 & 0.12 & 0.59 & 0.59 & 0.56 & Ep \\
\hline Alm/An & 0.66 & 0.66 & & & & & 0.27 & & 0.60 & 0.68 & 0.67 & & & & & & 0.33 \\
\hline Prp/Ab & 0.07 & 0.05 & & & & & 0.73 & & 0.05 & 0.06 & 0.09 & & & & & & 0.67 \\
\hline Grs/Or & 0.06 & 0.04 & & & & & 0.00 & & 0.21 & 0.18 & 0.07 & & & & & & 0.00 \\
\hline Sps & 0.21 & 0.24 & & & & & & & 0.14 & 0.08 & 0.17 & & & & & & \\
\hline
\end{tabular}

The amount of ferric iron was calculated from stoichiometric constraints. For amphibole, the Fe $3+$ content corresponds to the average from minimum and maximum constraints (Holland \& Blundy, 1994).

This article is protected by copyright. All rights reserved. 
Micaschist

Sample LH3

Analysis\# 280

Mineral

ep ilm

g1 g2

$\begin{array}{ll} & 36.88 \\ \mathrm{SiO}_{2} & 37.32\end{array}$

0.13

$\mathrm{Al}_{2} \mathrm{O}_{3} \quad 21.31$

27.59

1.61

0.02

29.21
7.59

7.59

9.34

0.11

0.00

0.00

1.65
22.48

0.00

0.01

0.00

0.00

0.00

0.00

100.00

95.23

Garnet-grunerite gneiss

\section{LH9}

$\begin{array}{lllllllllllllllll}285 & 304 & 203 & 204 & 206 & 201 & 209 & 212 & 037 & 041 & 209 & 025 & 018 & 019 & 023 & 013 & 006 \\ 106 & & & & & & & & & & & & & & \end{array}$

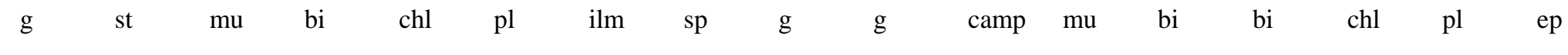
in and matrix matrix matrix matrix matrix matrix core rim matrix matrix matrix ing matrix in $g$ matrix in $g$

\begin{tabular}{|c|c|c|c|c|c|c|c|c|c|c|c|c|c|c|c|c|}
\hline $\begin{array}{l}35.50 \\
0.04\end{array}$ & 26.30 & 45.40 & 34.40 & 24.26 & 59.54 & 0.01 & 0.05 & 36.59 & 36.87 & 51.89 & 45.76 & 34.88 & 35.19 & 23.95 & 67.86 & 40.92 \\
\hline $\begin{array}{l}0.00 \\
51.42\end{array}$ & 0.57 & 0.37 & 1.49 & 0.20 & 0.01 & 52.69 & 0.05 & 0.15 & 0.06 & 0.02 & 0.03 & 1.20 & 1.39 & 0.08 & 0.01 & 0.00 \\
\hline $\begin{array}{l}20.67 \\
0.02\end{array}$ & 55.36 & 37.54 & 19.59 & 23.19 & 25.58 & 0.04 & 57.84 & 21.23 & 21.40 & 0.60 & 36.28 & 18.63 & 17.36 & 21.77 & 20.55 & 32.85 \\
\hline $\begin{array}{l}0.81 \\
0.11\end{array}$ & 0.98 & 0.40 & 8.53 & 12.06 & 0.02 & 0.03 & 1.51 & 0.65 & 1.50 & 12.11 & 0.36 & 9.04 & 8.48 & 12.33 & 0.00 & 0.01 \\
\hline $\begin{array}{l}26.02 \\
46.26\end{array}$ & 10.24 & 0.68 & 21.33 & 27.85 & 0.04 & 43.39 & 13.15 & 29.96 & 34.54 & 32.06 & 1.91 & 21.68 & 22.72 & 29.30 & 0.26 & 1.40 \\
\hline $\begin{array}{l}13.29 \\
0.18\end{array}$ & 0.52 & 0.00 & 0.19 & 0.39 & 0.00 & 3.54 & 0.22 & 3.67 & 0.40 & 0.05 & 0.00 & 0.00 & 0.00 & 0.03 & 0.00 & 0.04 \\
\hline $\begin{array}{l}0.00 \\
0.00\end{array}$ & 4.61 & 0.00 & 0.00 & 0.02 & 0.00 & 0.00 & 28.60 & 0.00 & 0.05 & 0.00 & 0.00 & 0.00 & 0.00 & 0.03 & 0.01 & 0.00 \\
\hline $\begin{array}{l}1.19 \\
0.13\end{array}$ & 0.04 & 0.00 & 0.00 & 0.03 & 7.01 & 0.02 & 0.03 & 8.02 & 5.84 & 0.35 & 0.04 & 0.06 & 0.06 & 0.03 & 1.00 & 23.66 \\
\hline $\begin{array}{l}0.00 \\
0.00\end{array}$ & 0.00 & 0.04 & 0.00 & 0.00 & 0.07 & 0.00 & 0.00 & 0.01 & 0.00 & 0.00 & 0.00 & 0.02 & 0.00 & 0.00 & 0.00 & 0.00 \\
\hline $\begin{array}{l}0.00 \\
0.00\end{array}$ & 0.08 & 0.88 & 0.07 & 0.00 & 7.48 & 0.03 & 0.35 & 0.00 & 0.00 & 0.09 & 0.19 & 0.08 & 0.06 & 0.00 & 10.74 & 0.49 \\
\hline $\begin{array}{l}0.00 \\
0.00\end{array}$ & 0.00 & 10.13 & 9.65 & 0.26 & 0.05 & 0.03 & 0.00 & 0.01 & 0.00 & 0.02 & 11.04 & 7.99 & 9.13 & 0.00 & 0.04 & 0.01 \\
\hline 100.29 & 98.70 & 95.44 & 95.25 & 88.28 & 99.80 & 99.77 & 101.80 & 100.27 & 100.66 & 97.18 & 95.62 & 93.57 & 94.39 & 87.52 & 100.46 & 99.36 \\
\hline
\end{tabular}
98.15

This article is protected by copyright. All rights reserved. 


\begin{tabular}{|c|c|c|c|c|c|c|c|c|c|c|c|c|c|c|c|c|c|c|}
\hline $\mathrm{Si}$ & $\begin{array}{l}2.99 \\
2.96\end{array}$ & $\begin{array}{l}2.91 \\
0.00\end{array}$ & 7.64 & 3.00 & 2.65 & 2.58 & 2.66 & 0.00 & 0.00 & 2.94 & 2.95 & 7.94 & 3.05 & 2.71 & 2.75 & 2.59 & 2.95 & 3.05 \\
\hline $\mathrm{Ti}$ & $\begin{array}{l}0.00 \\
0.01\end{array}$ & $\begin{array}{l}0.00 \\
0.99\end{array}$ & 0.12 & 0.02 & 0.09 & 0.02 & 0.00 & 1.00 & 0.00 & 0.01 & 0.00 & 0.00 & 0.00 & 0.07 & 0.08 & 0.01 & 0.00 & 0.00 \\
\hline $\mathrm{Al}$ & $\begin{array}{l}2.04 \\
2.58\end{array}$ & $\begin{array}{l}2.00 \\
0.00\end{array}$ & 18.95 & 2.93 & 1.78 & 2.91 & 1.35 & 0.00 & 1.98 & 2.01 & 2.02 & 0.11 & 2.85 & 1.71 & 1.60 & 2.78 & 1.05 & 2.89 \\
\hline $\mathrm{Fe}^{3+}$ & $\begin{array}{l}0.00 \\
0.50\end{array}$ & $\begin{array}{l}0.17 \\
0.01\end{array}$ & 0.00 & 0.00 & 0.00 & 0.00 & 0.00 & 0.00 & 0.04 & 0.08 & 0.07 & 0.02 & 0.00 & 0.00 & 0.00 & 0.00 & 0.00 & 0.09 \\
\hline $\mathrm{Mg}$ & $\begin{array}{l}0.20 \\
0.00\end{array}$ & $\begin{array}{l}0.10 \\
0.00\end{array}$ & 0.42 & 0.04 & 0.98 & 1.91 & 0.00 & 0.00 & 0.07 & 0.08 & 0.18 & 2.76 & 0.04 & 1.05 & 0.99 & 1.99 & 0.00 & 0.00 \\
\hline $\mathrm{Fe}^{2+}$ & $\begin{array}{l}1.98 \\
0.00\end{array}$ & $\begin{array}{l}1.79 \\
0.98\end{array}$ & 2.49 & 0.04 & 1.38 & 2.48 & 0.00 & 0.92 & 0.28 & 1.93 & 2.25 & 4.08 & 0.11 & 1.41 & 1.49 & 2.65 & 0.01 & 0.00 \\
\hline $\mathrm{Mn}$ & $\begin{array}{l}0.64 \\
0.00\end{array}$ & $\begin{array}{l}0.92 \\
0.00\end{array}$ & 0.13 & 0.00 & 0.01 & 0.04 & 0.00 & 0.08 & 0.01 & 0.25 & 0.03 & 0.01 & 0.00 & 0.00 & 0.00 & 0.00 & 0.00 & 0.00 \\
\hline $\mathrm{Zn}$ & $\begin{array}{l}0.00 \\
0.00\end{array}$ & $\begin{array}{l}0.00 \\
0.00\end{array}$ & 0.99 & 0.00 & 0.00 & 0.00 & 0.00 & 0.00 & 0.61 & 0.00 & 0.00 & 0.00 & 0.00 & 0.00 & 0.00 & 0.00 & 0.00 & 0.00 \\
\hline $\mathrm{Ca}$ & $\begin{array}{l}0.14 \\
1.91\end{array}$ & $\begin{array}{l}0.11 \\
0.00\end{array}$ & 0.01 & 0.00 & 0.00 & 0.00 & 0.34 & 0.00 & 0.00 & 0.69 & 0.50 & 0.06 & 0.00 & 0.01 & 0.01 & 0.00 & 0.05 & 1.89 \\
\hline $\mathrm{P}$ & $\begin{array}{l}0.00 \\
0.00\end{array}$ & $\begin{array}{l}0.00 \\
0.00\end{array}$ & 0.00 & 0.00 & 0.00 & 0.00 & 0.00 & 0.00 & 0.00 & 0.00 & 0.00 & 0.00 & 0.00 & 0.00 & 0.00 & 0.00 & 0.00 & 0.00 \\
\hline $\mathrm{Na}$ & $\begin{array}{l}0.00 \\
0.00\end{array}$ & $\begin{array}{l}0.00 \\
0.00\end{array}$ & 0.05 & 0.11 & 0.01 & 0.00 & 0.65 & 0.00 & 0.02 & 0.00 & 0.00 & 0.03 & 0.03 & 0.01 & 0.01 & 0.00 & 0.91 & 0.07 \\
\hline K & $\begin{array}{l}0.00 \\
0.00\end{array}$ & $\begin{array}{l}0.00 \\
0.00\end{array}$ & 0.00 & 0.86 & 0.95 & 0.04 & 0.00 & 0.00 & 0.00 & 0.00 & 0.00 & 0.00 & 0.94 & 0.79 & 0.91 & 0.00 & 0.00 & 0.00 \\
\hline $\mathrm{OH}$ & $\begin{array}{l}0.00 \\
1.00\end{array}$ & $\begin{array}{l}0.00 \\
0.00\end{array}$ & 0.00 & 2.00 & 2.00 & 8.00 & 0.00 & 0.00 & 0.00 & 0.00 & 0.00 & 0.00 & 2.00 & 2.00 & 2.00 & 8.00 & 0.00 & 1.00 \\
\hline Sum & $\begin{array}{l}7.99 \\
8.98\end{array}$ & $\begin{array}{l}8.00 \\
2.00\end{array}$ & 30.79 & 9.00 & 9.85 & 17.97 & 4.99 & 2.00 & 3.00 & 8.00 & 8.00 & 15.01 & 9.01 & 9.76 & 9.83 & 18.02 & 4.97 & 8.99 \\
\hline$X_{\mathrm{Mg}} / X_{\mathrm{Na}}$ & $\begin{array}{l}0.91 \\
0.46\end{array}$ & 0.95 & 0.85 & 0.12 & 0.58 & 0.56 & & & & 0.96 & 0.93 & 0.60 & 0.03 & 0.57 & 0.60 & 0.57 & Ep & 0.09 \\
\hline Alm/An & 0.67 & 0.61 & & & & & 0.34 & & & 0.65 & 0.76 & & & & & & 0.05 & \\
\hline Prp/Ab & 0.07 & 0.03 & & & & & 0.66 & & & 0.03 & 0.06 & & & & & & 0.95 & \\
\hline Grs/Or & 0.05 & 0.04 & & & & & 0.00 & & & 0.23 & 0.17 & & & & & & 0.00 & \\
\hline Sps & 0.22 & 0.32 & & & & & & & & 0.08 & 0.01 & & & & & & & \\
\hline
\end{tabular}

This article is protected by copyright. All rights reserved. 
Table 2: U-Th-Pb LA-ICP-MS data for the monazite grains in sample LH16.

\begin{tabular}{|c|c|c|c|c|c|c|c|c|c|c|c|c|c|}
\hline \# Analysis & Grain & {$[\mathrm{Pb}](\mathrm{ppm})$} & {$[\mathrm{U}](\mathrm{ppm})$} & {$[\mathrm{Th}](\mathrm{ppm})$} & $\mathrm{Th} / \mathrm{U}$ & $238 \mathrm{U} / 232 \mathrm{Th}$ & $\pm 1 \sigma$ & $206 \mathrm{~Pb} / 238 \mathrm{U}$ & $\pm 1 \sigma$ & $\begin{array}{l}\text { Ages }(\mathrm{Ma}) \\
206 \mathrm{~Pb} / 238 \mathrm{U}\end{array}$ & $\pm 1 \sigma$ & $\mathrm{Pb} 208 / 232 \mathrm{Th}$ & $\pm 1 \sigma$ \\
\hline $5100317 \mathrm{~b}$ & Mz1 & 658 & 3919 & 35930 & 9.2 & 0.0151 & 0.0002 & 0.0489 & 0.0007 & 307.5 & 4.1 & 302.0 & 3.7 \\
\hline $6100317 b$ & Mz1 & 499 & 3179 & 23612 & 7.4 & 0.0167 & 0.0002 & 0.0521 & 0.0007 & 327.7 & 4.4 & 334.0 & 4.1 \\
\hline $7100317 \mathrm{~b}$ & Mz1 & 628 & 4096 & 32565 & 8.0 & 0.0154 & 0.0002 & 0.0499 & 0.0007 & 313.7 & 4.2 & 308.0 & 3.8 \\
\hline $8100317 b$ & Mz2 & 730 & 5124 & 41280 & 8.1 & 0.0141 & 0.0002 & 0.0462 & 0.0006 & 291.3 & 3.9 & 282.8 & 3.5 \\
\hline $9100317 b$ & Mz2 & 711 & 4993 & 37805 & 7.6 & 0.0149 & 0.0002 & 0.0476 & 0.0007 & 299.8 & 4.0 & 298.4 & 3.7 \\
\hline $13100317 b$ & Mz2 & 760 & 5648 & 40266 & 7.1 & 0.0148 & 0.0002 & 0.0473 & 0.0007 & 298.0 & 4.0 & 296.3 & 3.6 \\
\hline $14100317 b$ & Mz2 & 762 & 5108 & 40338 & 7.9 & 0.0153 & 0.0002 & 0.0480 & 0.0007 & 302.0 & 4.1 & 306.6 & 3.8 \\
\hline $15100317 b$ & Mz2 & 859 & 6478 & 44899 & 6.9 & 0.0148 & 0.0002 & 0.0480 & 0.0007 & 302.4 & 4.1 & 297.6 & 3.7 \\
\hline $16100317 b$ & Mz2 & 663 & 4919 & 35128 & 7.1 & 0.0147 & 0.0002 & 0.0481 & 0.0007 & 302.8 & 4.1 & 295.4 & 3.7 \\
\hline $18100317 b$ & Mz3 & 377 & 3785 & 17002 & 4.5 & 0.0151 & 0.0002 & 0.0478 & 0.0007 & 300.8 & 4.1 & 302.2 & 3.8 \\
\hline $22100317 b$ & Mz3 & 756 & 7620 & 34540 & 4.5 & 0.0150 & 0.0002 & 0.0475 & 0.0007 & 299.4 & 4.1 & 301.0 & 3.8 \\
\hline $23100317 b$ & Mz4 & 715 & 5638 & 36727 & 6.5 & 0.0152 & 0.0002 & 0.0470 & 0.0007 & 296.3 & 4.1 & 305.7 & 3.8 \\
\hline $26100317 b$ & Mz4 & 881 & 6789 & 46472 & 6.8 & 0.0149 & 0.0002 & 0.0479 & 0.0007 & 301.7 & 4.2 & 299.1 & 3.8 \\
\hline $27100317 b$ & Mz5 & 613 & 3979 & 34046 & 8.6 & 0.0151 & 0.0002 & 0.0489 & 0.0007 & 308.0 & 4.3 & 301.9 & 3.8 \\
\hline $31100317 b$ & Mz5 & 810 & 4360 & 47466 & 10.9 & 0.0151 & 0.0002 & 0.0486 & 0.0007 & 306.0 & 4.3 & 302.7 & 3.8 \\
\hline $32100317 b$ & Mz5 & 465 & 3142 & 24584 & 7.8 & 0.0155 & 0.0002 & 0.0505 & 0.0007 & 317.6 & 4.4 & 310.4 & 3.9 \\
\hline $33100317 b$ & Mz7 & 351 & 8382 & 1641 & 0.2 & 0.0158 & 0.0002 & 0.0503 & 0.0007 & 316.3 & 4.3 & 317.5 & 4.1 \\
\hline $34100317 b$ & Mz9 & 969 & 10421 & 44908 & 4.3 & 0.0149 & 0.0002 & 0.0460 & 0.0007 & 289.8 & 4.0 & 298.1 & 3.8 \\
\hline $35100317 b$ & Mz9 & 924 & 9095 & 43862 & 4.8 & 0.0150 & 0.0002 & 0.0477 & 0.0007 & 300.1 & 4.2 & 300.7 & 3.8 \\
\hline $4100317 \mathrm{c}$ & Mz9 & 662 & 5115 & 34698 & 6.8 & 0.0147 & 0.0002 & 0.0479 & 0.0007 & 301.7 & 4.2 & 295.5 & 3.7 \\
\hline $5100317 \mathrm{c}$ & Mz10 & 779 & 7514 & 36612 & 4.9 & 0.0148 & 0.0002 & 0.0484 & 0.0007 & 304.6 & 4.2 & 296.7 & 3.7 \\
\hline $7100317 \mathrm{c}$ & Mz11 & 705 & 5752 & 36189 & 6.3 & 0.0147 & 0.0002 & 0.0480 & 0.0007 & 302.4 & 4.2 & 294.9 & 3.7 \\
\hline $13100317 \mathrm{c}$ & Mz16 & 711 & 4921 & 38637 & 7.9 & 0.0148 & 0.0002 & 0.0478 & 0.0007 & 300.9 & 4.2 & 297.2 & 3.7 \\
\hline $14100317 \mathrm{c}$ & Mz16 & 928 & 8021 & 45333 & 5.7 & 0.0150 & 0.0002 & 0.0475 & 0.0007 & 299.4 & 4.1 & 301.3 & 3.8 \\
\hline
\end{tabular}

This article is protected by copyright. All rights reserved. 


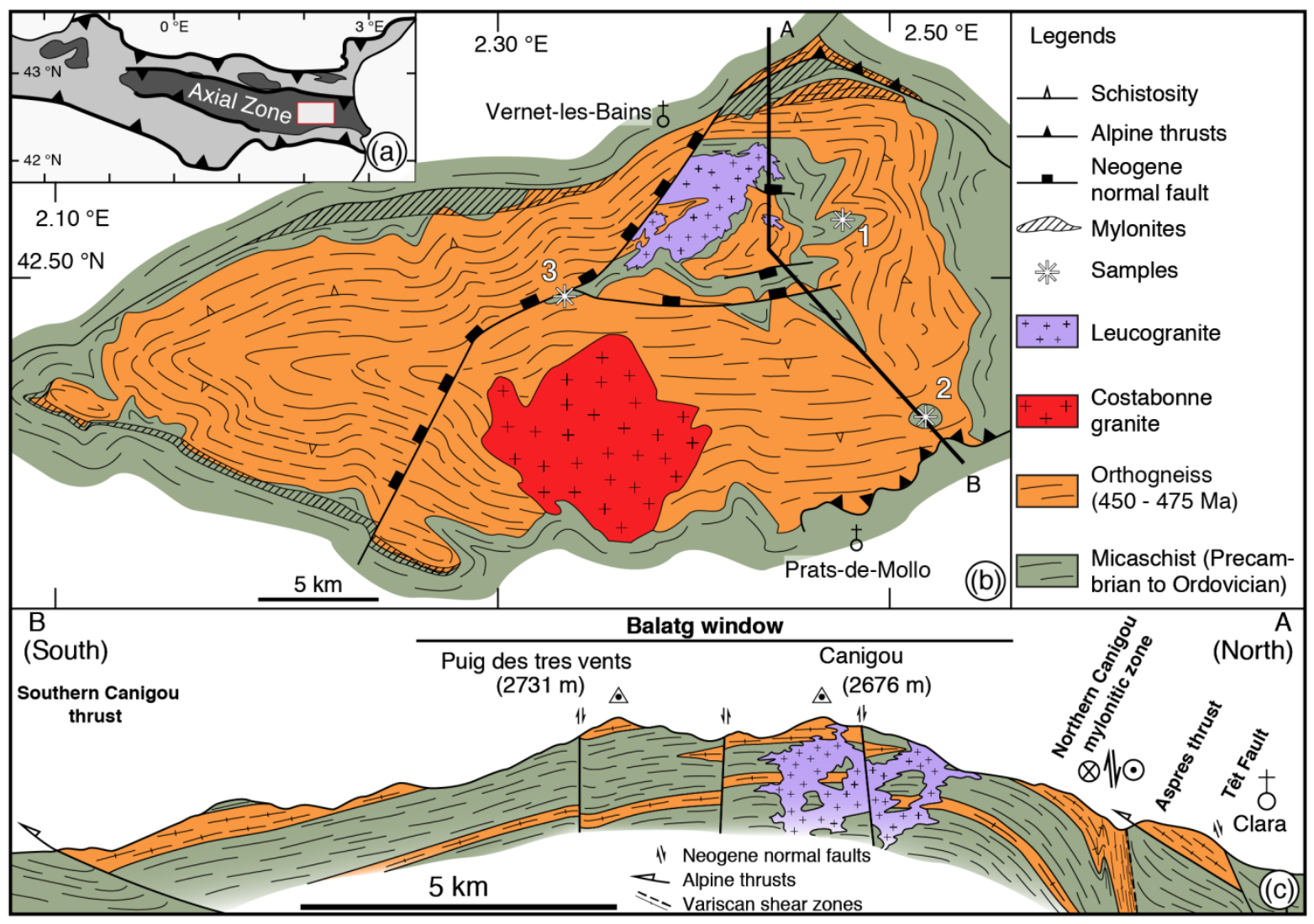

This article is protected by copyright. All rights reserved. 


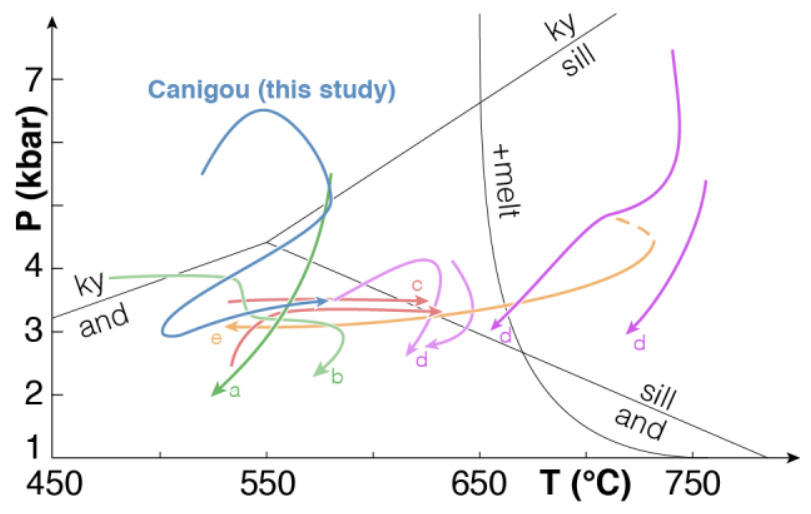

This article is protected by copyright. All rights reserved. 

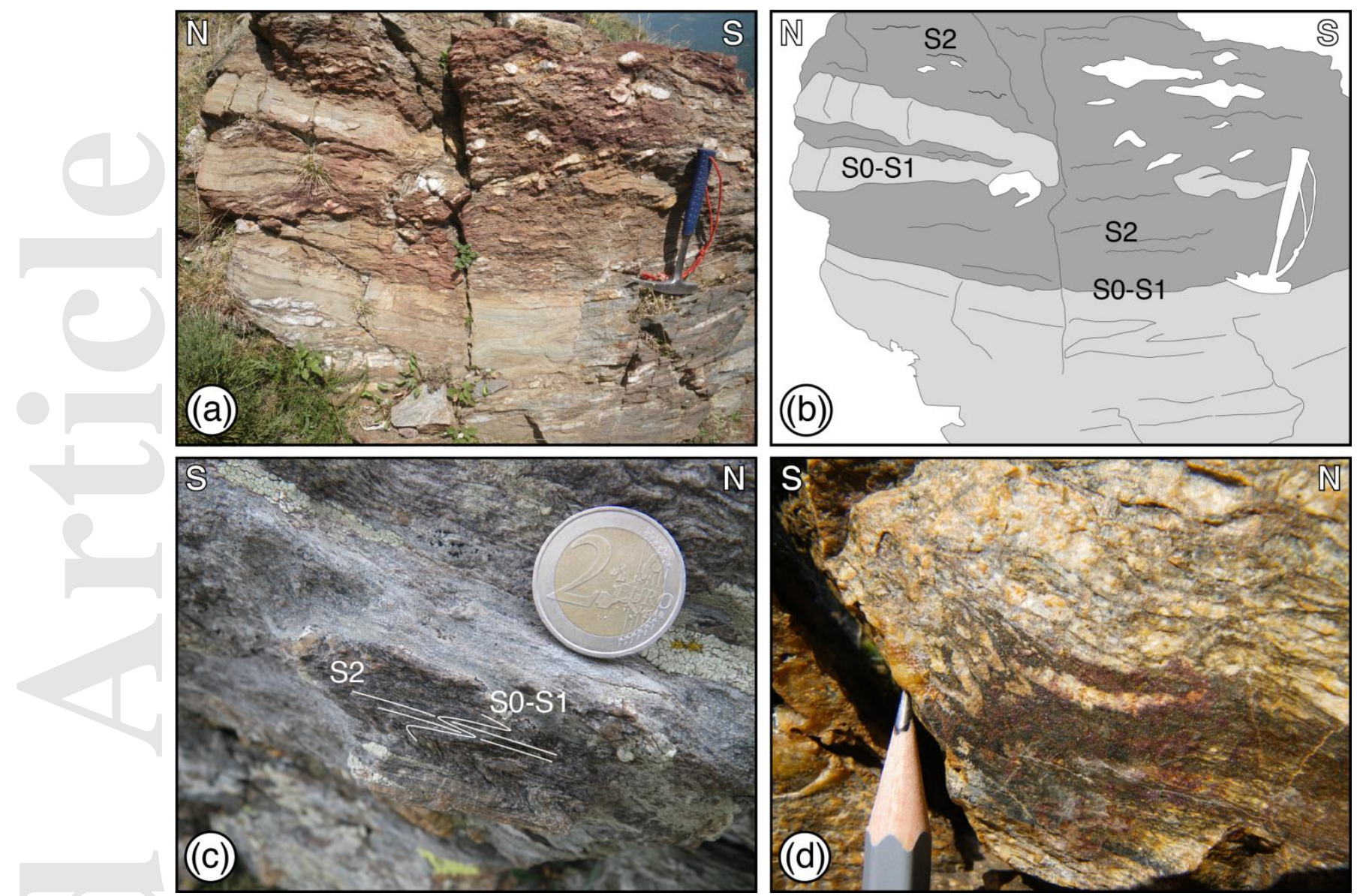

This article is protected by copyright. All rights reserved. 

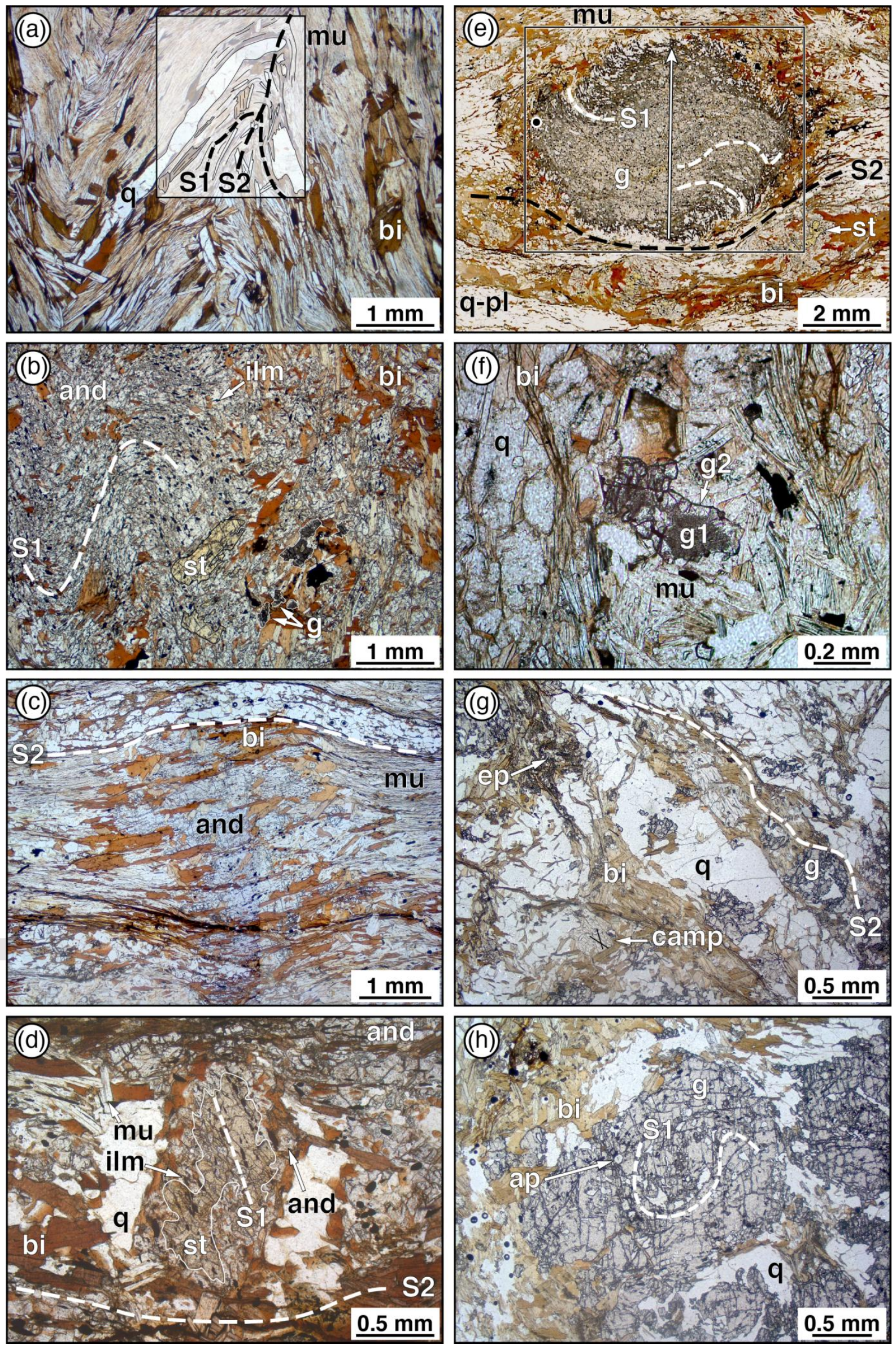

This article is protected by copyright. All rights reserved. 


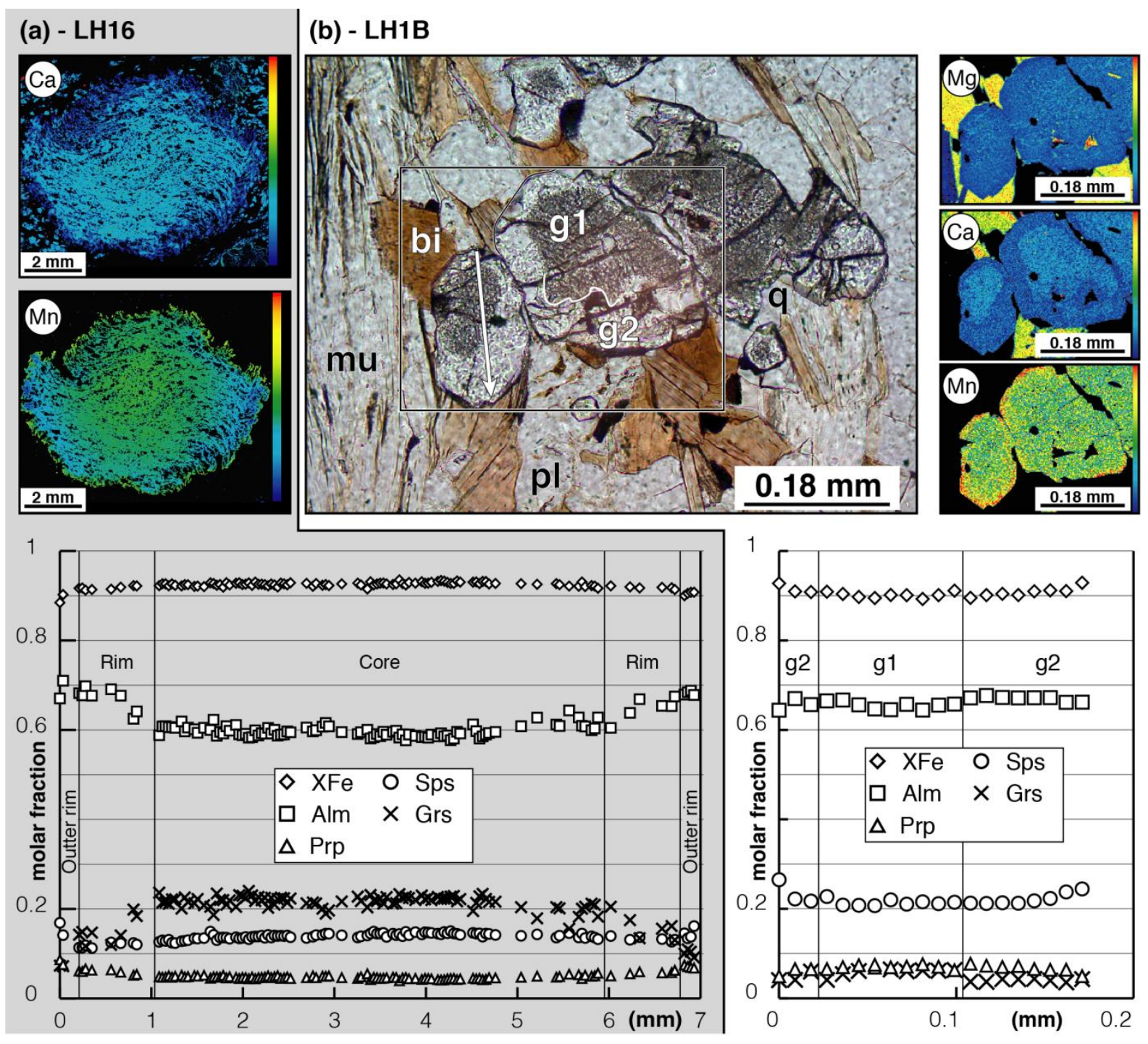

This article is protected by copyright. All rights reserved. 

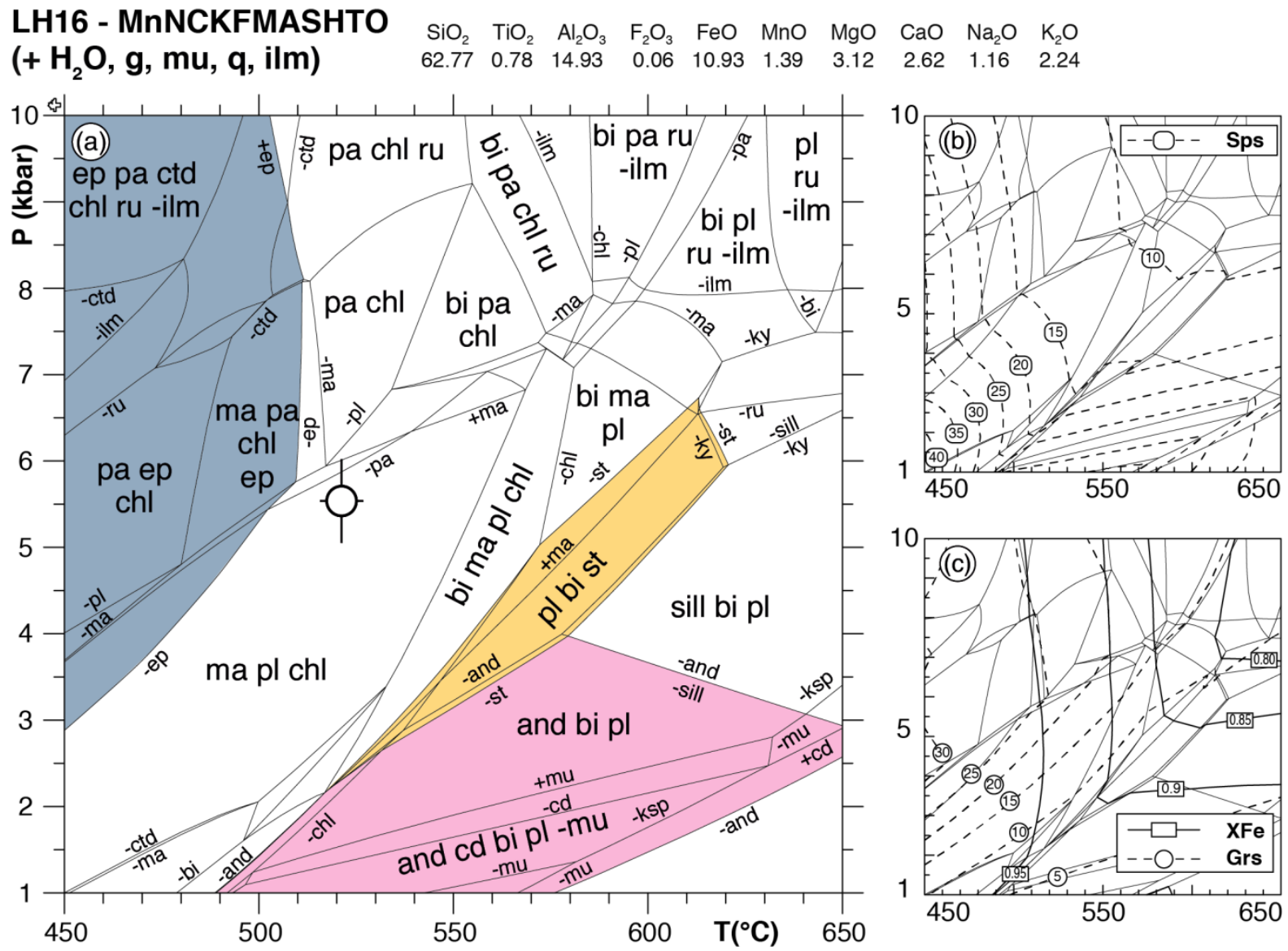

This article is protected by copyright. All rights reserved. 


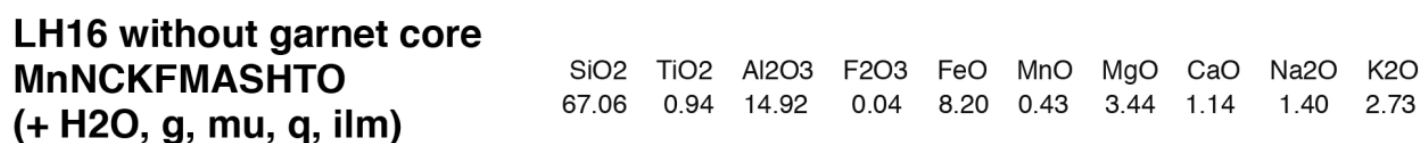

(+ H2O, g, mu, q, ilm)

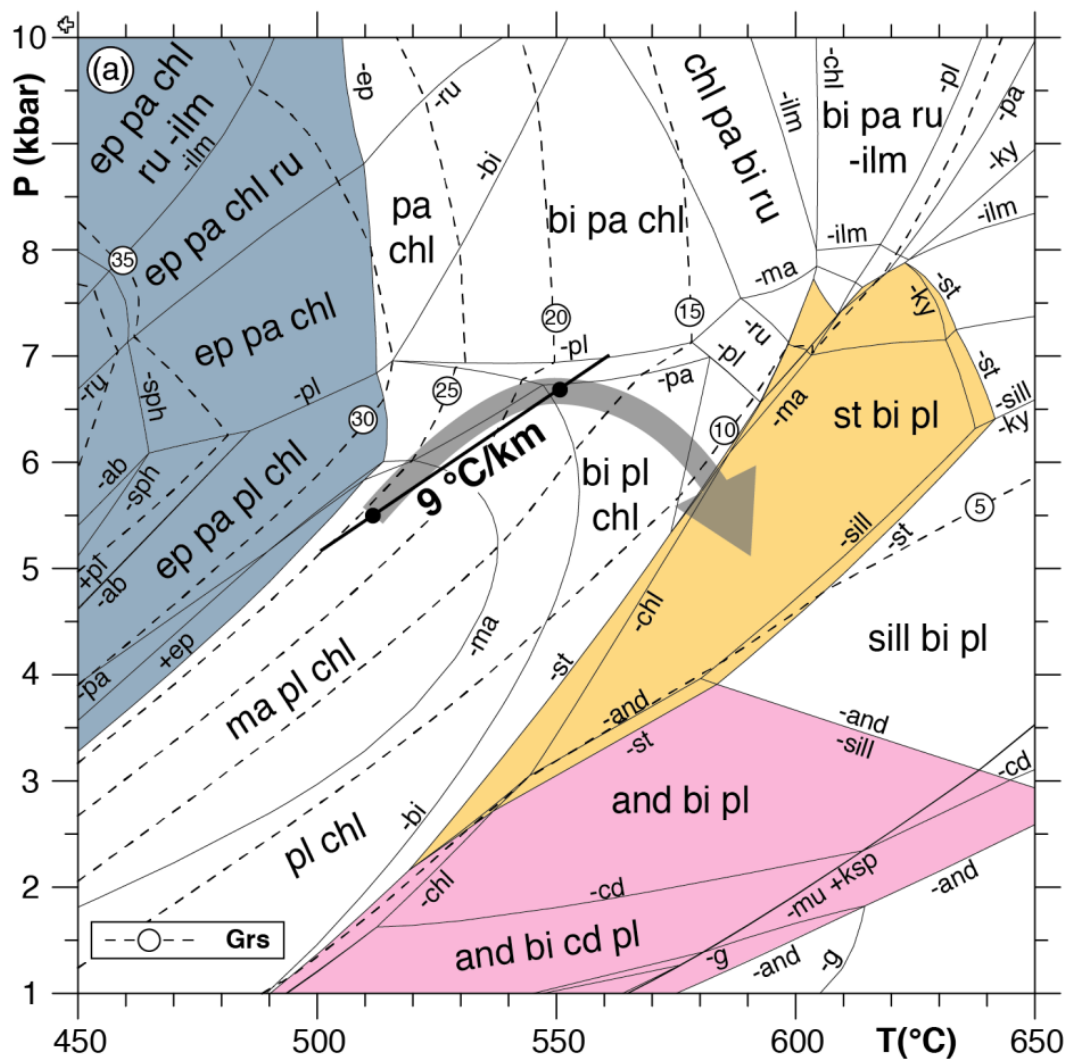

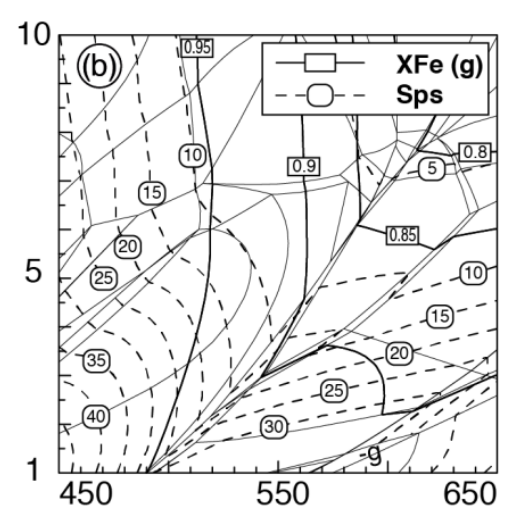

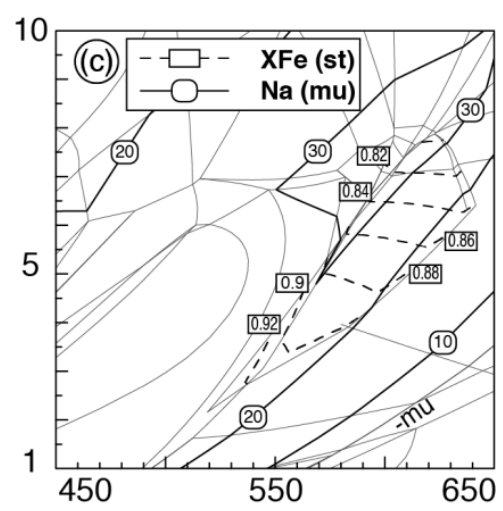

This article is protected by copyright. All rights reserved. 


\section{LH1B - MnNCKFMASHTO}

(+ H2O, mu, q, ilm)

$\mathrm{SiO} 2 \mathrm{TiO} 2 \mathrm{Al} 2 \mathrm{O} 3 \mathrm{~F} 2 \mathrm{O} 3 \mathrm{FeO} \mathrm{MnO} \mathrm{MgO} \mathrm{CaO} \mathrm{Na} 2 \mathrm{O}$ K2O

$\begin{array}{llllllllll}60.52 & 1.20 & 19.61 & 0.04 & 8.47 & 0.11 & 4.09 & 0.31 & 0.85 & 4.80\end{array}$

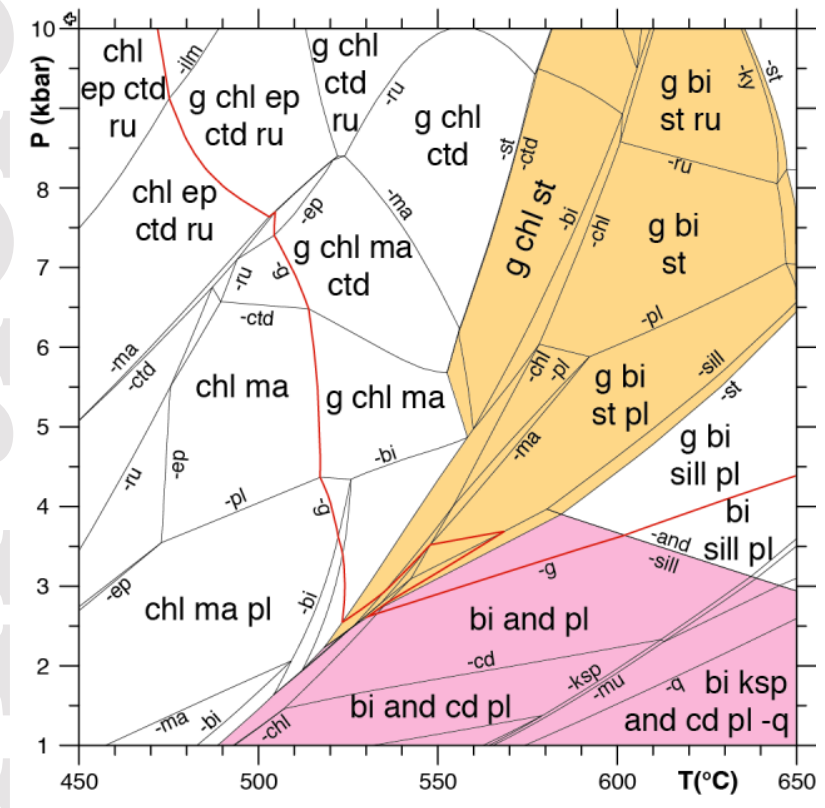

This article is protected by copyright. All rights reserved. 

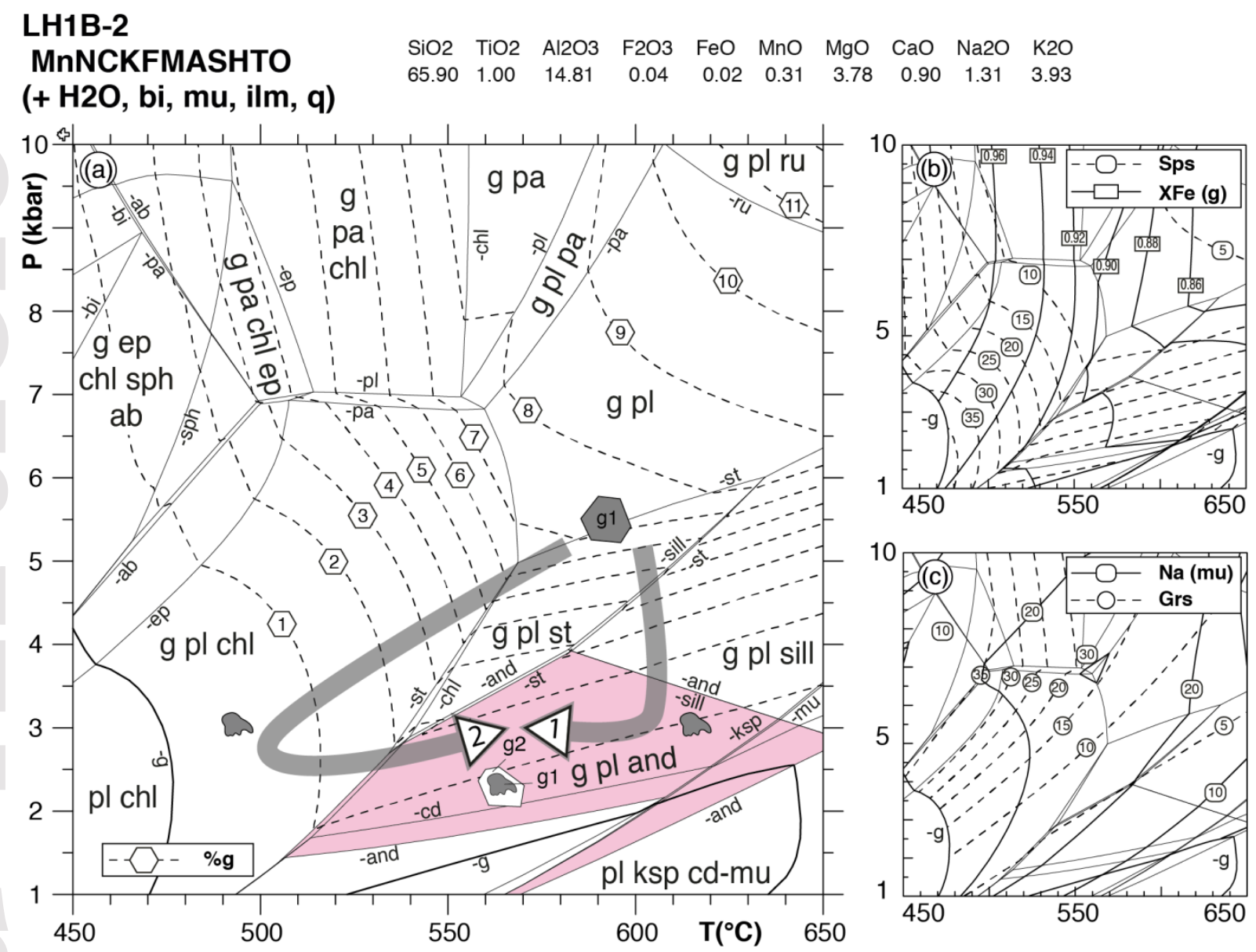

This article is protected by copyright. All rights reserved. 


$\begin{array}{lcccccccccc}\text { LH3 - MnNCKFMASHTO } & \mathrm{SiO} 2 & \mathrm{TiO} 2 & \mathrm{Al} 2 \mathrm{O} 3 & \mathrm{~F} 2 \mathrm{O} 3 & \mathrm{FeO} & \mathrm{MnO} & \mathrm{MgO} & \mathrm{CaO} & \mathrm{Na} 2 \mathrm{O} & \mathrm{K} 2 \mathrm{O} \\ \text { (+ H2O, bi, mu, q) } & 63.32 & 0.80 & 16.61 & 0.03 & 6.01 & 0.17 & 3.54 & 2.77 & 3.51 & 3.25\end{array}$
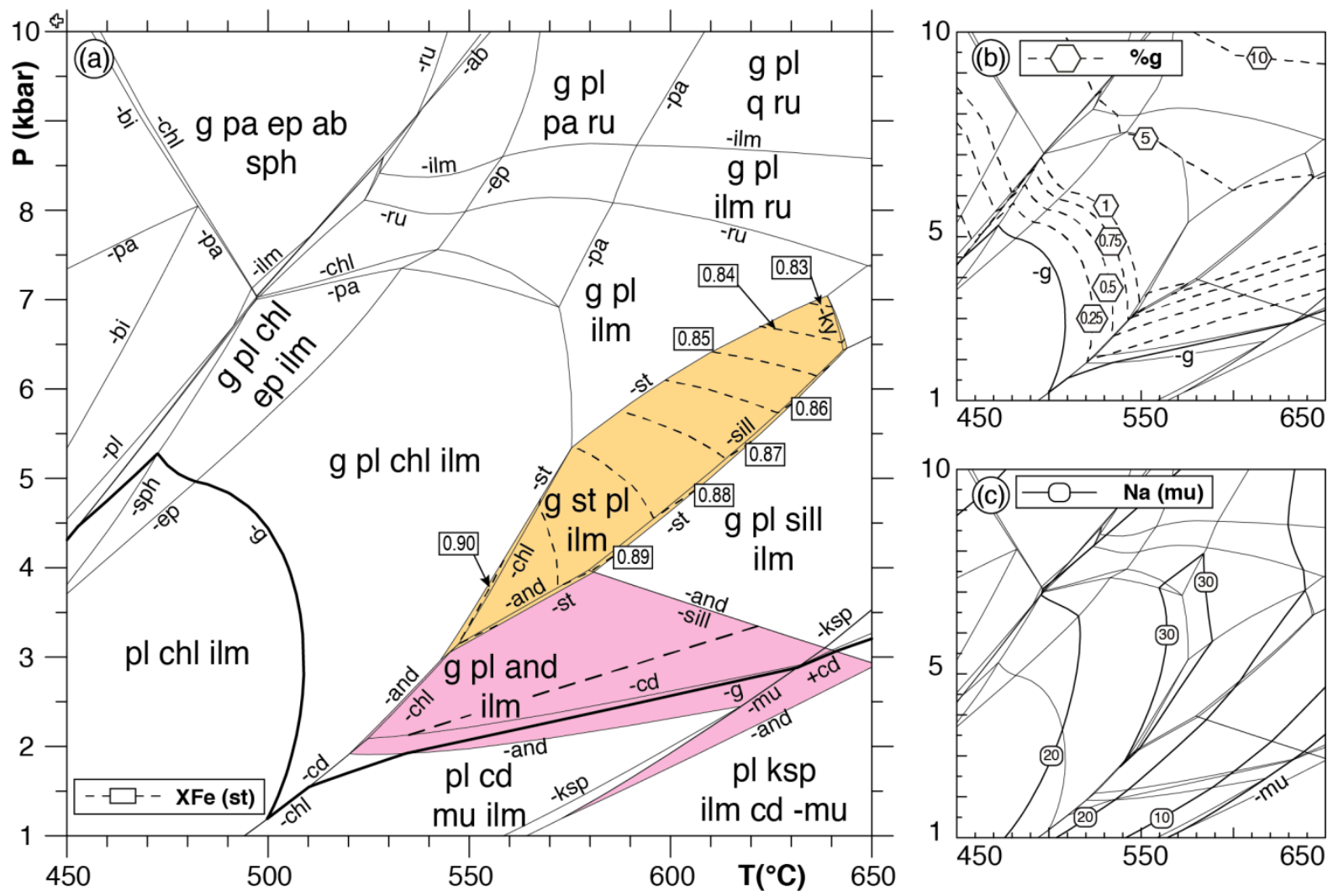

This article is protected by copyright. All rights reserved. 


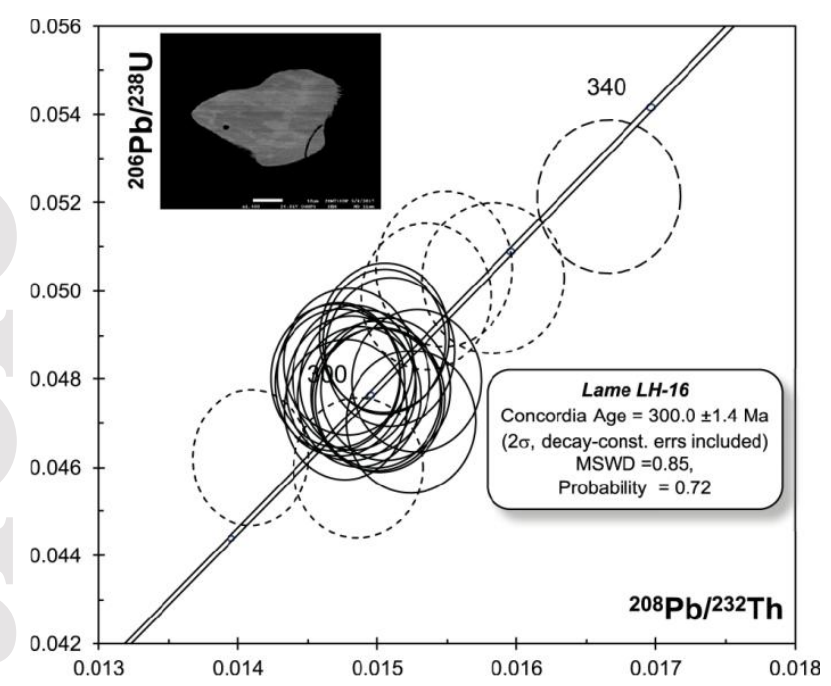

This article is protected by copyright. All rights reserved. 

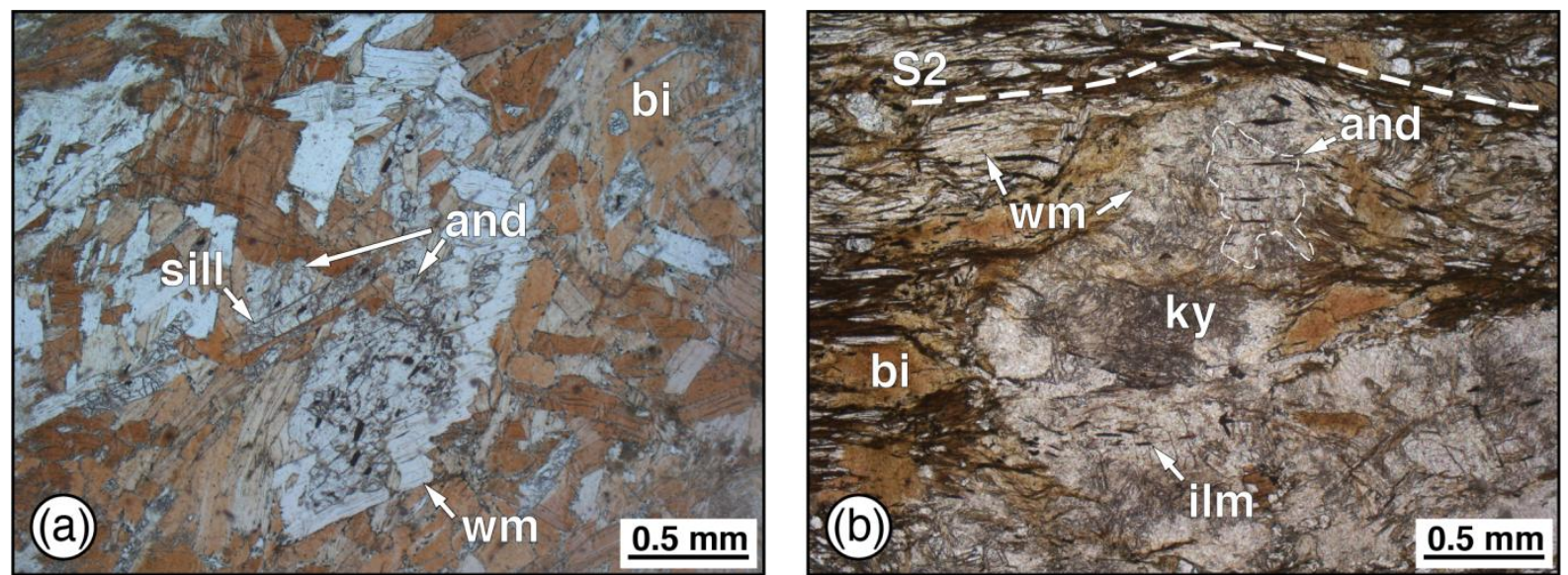

This article is protected by copyright. All rights reserved. 


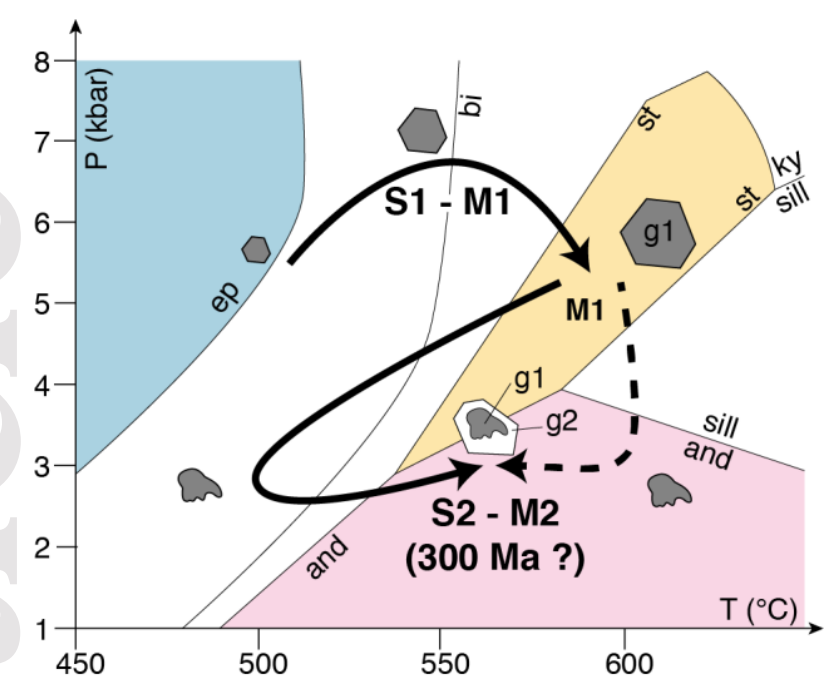

This article is protected by copyright. All rights reserved. 